\title{
Research on Fair Trade Consumption-A Review
}

\author{
Veronika A. Andorfer • Ulf Liebe
}

Received: 26 January 2011/Accepted: 11 August 2011/Published online: 28 August 2011

(C) The Author(s) 2011. This article is published with open access at Springerlink.com

\begin{abstract}
An overview and assessment of the current state of research on individual consumption of Fair Trade (FT) products is given on the basis of 51 journal publications. Arranging this field of ethical consumption research according to key research objectives, theoretical approaches, methods, and study population, the review suggests that most studies apply social psychological approaches focusing mainly on consumer attitudes. Fewer studies draw on economic approaches focusing on consumers' willingness to pay ethical premia for FT products or sociological approaches relying on the concept of consumer identity. Experimental, qualitative and conventional survey methods are used approximately equally often. Almost all studies draw on convenience or purposive samples and most studies are conducted in the USA or the United Kingdom. Several problems in current research are identified: amongst others, studies' rather narrow theoretical focus, potential hypothetical and social desirability bias of conventional survey data, and a lack of generalizability of empirical findings. In turn, we suggest that research would benefit from both a multiple-motives and a multiple-methods perspective. Considering competing theories can help to single out key behavioral determinants of individual FT consumption. The combination of different methods such as conventional
\end{abstract}

V. A. Andorfer $(\bowtie) \cdot$ U. Liebe

Universität Kassel, Steinstrasse 19, 37213 Witzenhausen,

Germany

e-mail: andorfer@uni-kassel.de

U. Liebe

Georg-August-Universität Göttingen, Platz der Göttinger

Sieben 5, 37073 Göttingen, Germany

e-mail: uliebe@uni-goettingen.de surveys and field experiments contributes to uncovering respondents' truthful answers and improves generalizability of results. Scholars in the field of ethical consumption research should use experiments to detect causal relations proposed by theories and conduct cross-country surveys to gather insights as to how differences in market structures, cultural traits, and other path dependencies affect patterns of individual FT consumption.

Keywords Choice experiment - Ethical consumption . Field experiment · Fair Trade consumption .

Theory of planned behavior

$\begin{array}{ll}\text { Abbreviations } \\ \text { AUS } & \text { Australia } \\ \text { BDM } & \text { Becker-DeGroot-Marschak mechanism } \\ \text { BE } & \text { Belgium } \\ \text { CA } & \text { Conjoint analysis } \\ \text { CDN } & \text { Canada } \\ \text { CE } & \text { Choice experiments } \\ \text { CH } & \text { Switzerland } \\ \text { CV } & \text { Continent valuation } \\ \text { D } & \text { Germany } \\ \text { ESP } & \text { Spain } \\ \text { F } & \text { France } \\ \text { FIN } & \text { Finland } \\ \text { FT } & \text { Fair Trade } \\ \text { HK } & \text { Hong Kong } \\ \text { IT } & \text { Italy } \\ \text { NL } & \text { Netherlands } \\ \text { PBC } & \text { Perceived behavioral control } \\ \text { ROK } & \text { South Korea } \\ \text { SVT } & \text { Schwartz' value theory } \\ \text { SWE } & \text { Sweden } \\ \text { TPB } & \text { Theory of planned behavior } \\ & \end{array}$


UK United Kingdom

USA United States of America

WTP Willingness to pay

\section{Introduction}

For an increasing number of consumers in affluent societies, the social features of products-such as decent living and working conditions for producers in developing countries-are important ethical criteria in their shopping strategies. Between 2004 and 2007, global certified sales of these Fair Trade (FT) products almost tripled, rising from $€ 832$ to $€ 2,381 \mathrm{~m}$ (Krier 2008). This growing importance of positive ethical purchase behavior in the market is matched by an increasing interest of scholars in the social and behavioral sciences in this phenomenon. Research on individual FT consumption has triggered publications in such diverse fields as agricultural sciences, consumer studies and marketing, economics, geography, social psychology, and (rural) sociology.

We seek to critically evaluate current publications on individual FT consumption that combine theoretical and empirical research, bringing together previously separate streams of academic work. On the basis of a structured overview of key research objectives, theoretical approaches, methods, study populations, and selected results, we aim at critically evaluating the current state of research on this topic. Identifying gaps, intersections, and inconsistencies in the application of theory and methods, we point out steps to be taken to advance research on the individual purchase of FT products within the broader framework of ethical consumption.

To the best of our knowledge, so far there are three reviews concentrating on individual FT consumption; yet these reviews either leave out empirical research on consumers' willingness to pay (Connolly and Shaw 2006), employ a very broad focus within the framework of ethical consumption (Newholm and Shaw 2007) or need to be updated (Tallontire et al. 2001).

Being well aware that it is neither easy nor unproblematic to define selection criteria for publications to be included in a review, this article comprises English-language journal articles that complement theoretical approaches with the presentation of empirical research. We excluded publications solely concentrating on theoretical explanations to FT consumption as we are interested in how theoretical propositions fare in empirical settings. We included articles if scholars analyze individual consumption of products manufactured according to ethical criteria for the living and working conditions of humans in developing countries. Hence, we excluded articles covering other forms of individual ethical consumption (e.g., purchase of organic food or products not tested with animals, consumer boycotts, consumer lobbying, ethical investment strategies), other aspects of the international FT regime (e.g., small-scale producers, retailers, certifying bodies, and other corporate actors) or aspects of domestic FT regimes in affluent countries. ${ }^{1}$ In total, we selected 51 articles to be included in this review.

This article is organized as follows. We divided the current state of research on individual consumption of FT products into two major research objectives and structured it along four questions in the next section: Which theoretical approaches do authors consult in explaining individual FT consumption? Which methods are used to test propositions? What kind of study population are the results based on? What selective results do the studies lead to? Based on this overview, we then critically assess the current state of research by identifying relations between strands of research and by pointing out inconsistencies and gaps. The article concludes with suggestions of future steps to be taken to advance research on FT consumption.

\section{Overview of Empirical Research on Individual Fair Trade Consumption}

Assessing the current state of empirical research on individual FT consumption, we identify two key research objectives: first, the purchase of FT products analyzed in terms of consumer preferences for ethical product features (i.e. choices between products) and, second, individual FT consumption understood in terms of consumer attitudes and motivations (i.e. evaluation of a single product). In large part, research to date has focused on consumers' attitudes and motivations toward FT consumption and the contexts they are formed in. By contrast, fewer studies rely on the concept of consumer preferences when analyzing FT consumption. $^{2}$

The main difference between these two key research objectives is that within a preference-based approach consumers' choices between product alternatives are the key explanatory variable, whereas the key explanatory factors in an attitude-based and motivation-based approach are expressed in terms of an object's or action's desirability

\footnotetext{
${ }^{1}$ Howard and Allen (2008) as well as Zander and Hamm (2010) investigate consumers' willingness to pay for products that have been manufactured according to Fair Trade principles in countries of the Global North.

${ }^{2}$ Historically, this scarcity might be due to the rejection of the basic assumptions about "homo oeconomicus" in consumer research and a turn toward more social psychological, sociological and anthropological explanations as opposed to managerial marketing studies in the 1950s (Lawson 2010).
} 
for consumers (Green and Tunstall 1999, p. 222; Kahneman et al. 1999). Within the latter research objective, it is assumed that behavior can be predicted by attitudes, motivations or consumers' positive inner dispositions toward FT in general. It is the contexts in which these are formed that are of interest to researchers from social psychology and sociology. By contrast, the actions consumers take are central to the preferences approach in FT consumption, typically employed in economics. Assuming that choices between alternative courses of action-that is, consumers' choices between product alternatives-are subject to sacrifices and prioritizing of scarce resources, preferences are seen as stable and substitutable.

The studies presented in Appendix (Table 5) are primarily categorized according to their key research objective. The first part of the table comprises 17 articles that analyze FT consumption in terms of consumers' preferences; the second part comprises 34 articles that analyze FT consumption in terms of consumer attitudes and motivations. For each of these studies, we specify the theoretical approaches they rely on, the methods used, sample type, country focus and briefly summarize selected results.

\section{Theoretical Approaches in Research on Fair Trade Consumption}

\section{Economic Approaches}

According to the basic economic model, individuals make choices between alternative courses of action that will maximize their expected utility. Regarding the purchase of products, the basic economic model in consumer theory concentrates primarily on product price and consumer's budget restriction. Within their budget restrictions, consumers choose the product alternative that gives them the highest expected utility per cost unit. In deciding which product to consume, a person's preferences are revealed (Sugden 1999).

Modeling consumer preferences according to the 'Characteristics Theory of Value' (Lancaster 1966) and the 'Random Utility Theory' (McFadden 1974), it is assumed that utility is derived from the characteristics of goods (not from the goods per se) and that the utility of product alternatives is a latent construct that only exists in the minds of individual consumers. Researchers are not able to observe this directly. Yet, indirect measurement techniques can be used to explain a significant part of the latent utility construct. An error component determined by additional unobservable attributes, measurement errors, and variation between individual consumers, however, remains unexplained.

The estimation of consumers' willingness to pay (WTP) a premium for the ethical features of FT products is a

prevalent research objective of studies based on economic explanations. Consumers buying the more expensive FT product reveal their preferences for the ethical features of a product and, consequently, these consumers gain additional utility from these characteristics. The studies included in this review mostly focus on the estimation of consumers' WTP for FT coffee (Arnot et al. 2006; Carlsson et al. 2010; Cranfield et al. 2010; Basu and Hicks 2008; De Pelsmacker, Driesen et al. 2005a; Galarraga and Markandya 2004; Loureiro and Lotade 2005; Trudel and Cotte 2009), FT chocolate (Didier and Lucie 2008; Rousu and Corrigan 2008), and sweatshop-free clothing (Auger et al. 2003; Dickson 2001; Hustvedt and Bernard 2010; Prasad et al. 2004; Rode et al. 2008). In addition, some studies explicitly investigate the effect of product information transmitted via FT labels on the amount consumers are willing to pay extra for FT products (Basu and Hicks 2008; Dickson 2001; Didier and Lucie 2008; Hustvedt and Bernard 2010; Rousu and Corrigan 2008), the effect of social context on individual FT consumption (Carlsson et al. 2010), and the effect of FT characteristics on consumers' brand loyalty (Cailleba and Casteran 2010).

\section{Social Psychological Approaches}

Studies drawing on theoretical approaches from social psychology are not primarily interested in consumers' product choice with regard to utility maximization and the measurement of consumers' WTP in monetary terms. Rather, authors rely on a diverse set of explanatory concepts to investigate the contexts within which ethical consumer intentions are formed.

As can be seen from Table 1, three major explanatory concepts have been identified: first, consumer attitudes mostly analyzed with extended and modified versions of Ajzen's (1991) Theory of Planned Behavior (TPB) or within a more general attitude-behavior paradigm $(n=15)$; second, studies using the concept of information and communication to

Table 1 Theoretical approaches in empirical research on Fair Trade consumption

\begin{tabular}{lr}
\hline Theoretical approach & $N$ \\
\hline $\begin{array}{l}\text { Economics } \\
\text { Consumer }\end{array}$ & 17 \\
$\quad$ willingness to pay & \\
Social psychology & \\
Consumer attitudes & 15 \\
Information and & 8 \\
$\quad$ communication & \\
Consumer values & 6 \\
Sociology & \\
Consumer identity & 5 \\
Total & 51 \\
\hline
\end{tabular}


explain the purchase of FT products and the formation of consumer segments $(n=8)$; third, consumer values mostly analyzed in terms of Schwartz's Value Theory (SVT; $n=6$; Schwartz 1994; Schwartz and Bilsky 1990).

\section{Consumer Attitudes}

Ajzen's TPB is a prominent approach within the attitudebehavior paradigm in social psychology. It has been applied to a variety of behavioral phenomena (see Armitage and Conner 2001 for a meta-analytic overview). According to Ajzen's model (Ajzen 1991), the behavior of interest (e.g., buying FT products) is determined by the intention to perform this behavior, which in turn is influenced by the attitude toward that behavior (i.e., an individual's positive or negative assessment of buying FT products), a subjective norm (i.e., an individual's perception of social pressure from significant others to consume FT products), and perceived behavioral control (PBC; i.e., an individual's perception of difficulties in and obstacles to buying FT products). The 14 studies included in this subcategory either extend or modify Ajzen's basic model, analyze selected elements of it, or focus on more general aspects of consumer attitudes.

To increase the predictive power of the TPB, Shaw et al. (2000) and Ozcaglar-Toulouse et al. (2006) extend Ajzen's basic model by two determinants that are theorized to affect consumers' behavioral intention to buy FT products: (1) ethical obligation, understood as "[...] an individual's internalized ethical rules, which reflect their personal beliefs about right and wrong" (Shaw et al. 2000, p. 881 f.), and (2) self-identity, which is defined as ethical concerns becoming central to an individual's identity (p. $882 \mathrm{f}$.).

To further improve Ajzen's TPB with regard to the explanation of FT consumption, four other extensions concerning (a) the formation of ethical beliefs (Shaw and Clarke 1999), (b) volitional and motivational processes (Shaw et al. 2007), (c) consumers' neutralization mechanisms (Chatzidakis et al. 2007) and (d) consumer socialization processes (Nicholls and Lee 2006) have been proposed.

Modifying Ajzen's basic logic of attitudes determining behavior, De Pelsmacker and Janssens (2007) propose a conceptual framework in which the purchase of FT products is determined by a general attitude toward the FT issue (i.e., concern/interest and skepticism/lack of belief in FT) and a specific attitude toward FT products (i.e., product interest, product likeability, shopping convenience, and price acceptability), which are in turn influenced by the consumer's knowledge about this issue. Assuming that being better informed leads to more positive attitudes toward FT, these should lead to an increase in buying behavior. Thus, information about FT issues moderates the relationship between attitudes and buying behavior.

Studies analyzing selected elements of the TPB primarily investigate the influence of perceived behavioral control on FT consumption, referring either explicitly (Shaw et al. 2006b) or implicitly (Tanner and Kast 2003; Uusitalo and Oksanen 2004) to Ajzen's TPB. In these studies, the price of FT products is seen as an obstacle to buying FT products in addition to other difficulties such as a lack of ethical product alternatives or FT retail outlets. In addition, focusing exclusively on the link between consumers' attitudes and their intention to buy personalized FT clothing, Halepete et al. (2009) theorize that consumers' need for self-uniqueness positively influences their attitudes toward personalization of FT apparel.

In addition, we identify several studies that focus on more general aspects of consumer attitudes, which are not explicitly theorized in terms of the TPB: the effect of international awareness and social concern for others (Nijssen and Douglas 2008), the effect of consumers' global cognitive orientation on FT consumption (Goig 2007), the importance of consumers' socially responsible attitudes for individual FT consumption (Kim et al. 1999) and the influence of attitudes toward human rights (Hertel et al. 2009) on FT purchasing intentions.

\section{Information and Communication}

The role of information and communication in FT consumption is mostly discussed from a marketing perspective. Studies focus primarily on strategies to profitably satisfy consumer needs as well as on identifying consumer segments to successfully place FT products in the market. Research on the effect of labels, which help consumers to identify food and other commodities as FT certified, features most prominently in this second subcategory. In contrast to studies analyzing ethical consumption in terms of consumer preferences, the effect of social labels is not investigated with regard to consumers' WTP.

Howard and Allen (2010) embed their argument on social labeling within the concept of ethical and political consumerism. In much the same way as citizens influence the political sphere by voting, consumers can use the power of their purse to promote moral causes within society as a whole. Friedman (1996, p. 440) uses the term 'buycott' to denote "[...] attempt[s] to induce shoppers to buy the products or services of selected companies in order to reward them for behavior which is consistent with the goals of the activists." Drawing on this notion of positive consumer action, Howard and Allen (2010) argue that social labels facilitate consumers' buycotts by providing extra information from third parties on the production process of FT commodities. 
To the extent that the scholars theorize their arguments, De Pelsmacker et al. (2005b), Grankvist et al. (2007), and Poelman et al. (2008) also investigate how product information transmitted via social labels influences consumers' perception of FT products. Although basic theoretical foundations within social psychological theories such as Ajzen's TPB or sociological concepts of political consumerism are largely missing in these studies, information on FT standards and issues is assumed to exert a positive effect on consumer attitudes and motivations since information asymmetries between producer and consumer of FT products are reduced and the credibility of FT claims is increased.

Research focusing on the more general aspects of information and communication in FT consumption analyzes the effect of concrete versus abstract information about the living conditions of small-scale producers (d'Astous and Mathieu 2008), or the effectiveness of communication strategies on consumers' attitudes (Wright and Heaton 2006). Searching for strategies to successfully place FT products in the market, Carrigan et al. (2004) and Littrell et al. (2005) investigate whether the consumer segment of the elderly differs with regard to consumer attitudes and motivations to buy FT products.

\section{Consumer Values}

The third subcategory comprises consumer values and their role in the consumption of FT products. Schwartz and Bilsky (1990, p. 878) define individual values as "concepts or beliefs, pertaining to desirable end states, which transcend specific situations, guide selection or evaluation of behavior and events, and are ordered by relative importance." Assuming that values exist which can be found in all human societies, the Schwartz Value Theory (SVT, Schwartz 1994) identifies ten motivationally distinct value types $^{3}$ and characterizes compatible or conflicting relationships between them. Based on the SVT, FT consumers' characteristics are investigated in terms of personal values (Doran 2009, 2010; Shaw et al. 2005). Drawing in part on SVT, Doran and Natale (2011) argue that religious consumers are more inclined to buy FT products because of their pronounced ability to feel empathic concern.

Although not explicitly connected to the framework of SVT, consumers' personal values are also theorized to differ with regard to the retail store they primarily frequent to buy such products (de Ferran and Grunert 2007). Analyzing the role of consumers' ethical value systems as domain-specific personal values that are expressed through

\footnotetext{
3 These ten value types are: universalism, benevolence, conformity, tradition, security, power, achievement, hedonism, stimulation, and self-direction (Schwartz 1994).
}

ethical consumption behavior, Kim et al. (2010) argue that ethical consumption values primarily determine consumers' loyalty toward FT brands directly and indirectly through consumers' beliefs about FT products and their evaluation of FT companies.

\section{Sociological Approaches}

Personal and, above all, social identity has long been a central concept in sociological thought (see Callero 2003; Cerulo 1997 for an overview of the evolution of sociological identity research). Sociologists such as Giddens (1991) or Bauman (1988) see consumption as an identity project central to the individual expression of self-meaning and personal selection of self-image in late modernity; through consumption individuals try to answer-both for themselves and for others - the question of 'Who am I?' (Gabriel and Lang 2006). The studies reviewed in this article conceptualize the purchase of FT products as a means to exert influence in the market through 'consumer citizenship' (Dickinson and Carsky 2005) and as a means of expressing a moral dimension of lifestyles in affluent consumer societies. In contemporary consumer societies (see Zukin and Maguire 2004 for an overview of research on consumer society), important aspects of everyday life are expressed through monetary transactions, and individual behavior is perceived as being strongly affected by market forces. Therefore, consumption is seen as an important means of influencing social outcomes on a collective level and of constructing personal consumer identity.

In their exploratory study, Shaw et al. (2006a) discuss the concept of 'consumption as voting' with regard to various forms of ethical consumption behavior. Consumers' decisions to purchase FT products or sweatshop-free clothes are seen in terms of an active struggle for consumer power within the framework of collective consumer behavior. Varul $(2009,2010)$ complements the notion of ethical or political consumerism understood as power of the purse by arguing that purchasing FT products is not only a means of 'doing good' but also of expressing consumer identity as a moral person ('being good'). Using Barnett et al.'s (2005) term 'ethical selving' to describe "[...] the ways in which Fair Trade consumers engage in the construction, affirmation and communication of ethical selves" (Varul 2009, p. 183), it is argued that consumers of FT products express their concerns about mass consumption, and distinguish themselves from conventional shoppers, thereby constructing their consumer identity as moral persons. This argument is further corroborated by the notion of FT consumption as a link between ethics and consumption in everyday shopping behavior (Adams and Raisborough 2010) and the concept of voluntary simplicity (Shaw and Newholm 2002). 
Table 2 Methods used in empirical research on Fair Trade consumption

\begin{tabular}{lrrrr}
\hline Methods over all studies & $N$ & \multicolumn{3}{l}{ Methods by theoretical approach } \\
\cline { 3 - 5 } & & Economics & $\begin{array}{l}\text { Social } \\
\text { psychology }\end{array}$ & Sociology \\
\hline Experiments $^{\mathrm{a}}$ & 17 & 12 & 5 & - \\
Surveys $^{\mathrm{b}}$ & 15 & 1 & 14 & - \\
Qualitative approaches $^{\mathrm{c}}$ & 14 & - & 8 & 6 \\
$\begin{array}{l}\text { Contingent valuation } \\
\quad \text { method }\end{array}$ & 4 & 3 & 1 & - \\
$\begin{array}{l}\text { Hedonic approach } \\
\text { Total }\end{array}$ & 1 & 1 & - & - \\
\hline
\end{tabular}

${ }^{a}$ Include lab experiments $(n=5)$, conjoint analyses $(n=4)$, choice experiments $(n=4)$, natural field experiments $(n=3)$ and artificial field experiment $(n=1)$

b Include one study using a household panel that combines households' actual purchasing behavior recorded from supermarket scanners and survey the consumption motivations of participating households (Cailleba and Casteran 2010)

c Include in-depth interviews $(n=7)$, focus group discussions $(n=5)$, means end-chain analysis $(n=1)$, and content analysis $(n=1)$

\section{Methods in Research on Fair Trade Consumption}

The studies included in this review use a diverse set of methods to empirically investigate individual FT consumption. Table 2 shows the distribution of methods over all studies and decomposed by theoretical approaches. Methods with experimental designs are used by 17 studies which predominantly employ an economic approach. Another 15 studies use surveys with almost all of them relying on social psychological explanations. The 14 studies utilizing qualitative methods are mainly located within a social psychological or sociological framework. Four studies rely on contingent valuation (CV) and one study employs a hedonic approach ${ }^{4}$ to elicit consumers' WTP for FT products. Both methods prevail in economic studies.

\section{Qualitative Approaches}

Studies that aim at reconstructing the contexts in which FT products are purchased and consumed, rely on qualitative approaches to gather knowledge about different aspects of

\footnotetext{
${ }^{4}$ Assuming that consumers reveal their ethical preferences by purchasing FT products, WTP can be derived from directly observing their consumption behavior in the market. For the hedonic approach, the value of private goods is decomposed into their separate price elements, which are related to different product characteristics (e.g., brand, size, origin, and ethical features). Market data are used to calculate a hedonic price function and then to elicit WTP for ethical product features (see Palmquist 1991 for a comprehensive introduction).
}

FT consumption in everyday life and to formulate tentative propositions about ethical consumption behavior. Seven of the 14 studies reviewed in this subcategory use in-depth interviews with ethical consumers to gain preliminary insights into the construction of collective consumer behavior and consumers' identity as moral persons (Shaw et al. 2006a; Shaw and Newholm 2002, also using focus group discussions; Varul 2009, 2010, also using content analysis), their use of neutralization mechanisms (Chatzidakis et al. 2007), global cognitive orientation (Goig 2007), the role of the elderly as ethical consumers (Carrigan et al. 2004), and the influence of values (Shaw et al. 2005, also using focus group discussions). Tentative propositions about the formation of consumer beliefs on FT products (Shaw and Clarke 1999), the role of children as ethical consumers (Nicholls and Lee 2006) and the effectiveness of communication in product marketing (Wright and Heaton 2006) are formulated after gathering material in focus group discussions. Consumers' autobiographical writings about their everyday experiences of ethics and shopping in the Mass Observation Archive-a collection of British qualitative longitudinal social data of personal in-depth accounts (see http://www.massobs.org.uk for an overview) - are explored using content analysis (Adams and Raisborough 2010). De Ferran and Grunert (2007) employ means-end chain analysis - a qualitative method from consumer research (Gutman 1982) - to investigate how consumers link the attributes of FT products to underlying motives and values.

\section{Surveys}

Compared to qualitative approaches, a more standardized method of gaining insights into consumers' ethical purchase behavior and their attitudes and motivations toward FT, is by conducting surveys. Combining data from supermarket scanners with surveys on the household level, household panels allow the study of consumers' actual purchasing behavior and their attitudes and motivations for buying certain products over time. At present, only Cailleba and Casteran (2010) use such data to investigate brand loyalty toward FT products.

Cross-sectional surveys are used to study the role of personal values in FT consumption (Doran 2009, 2010), the store image of FT retail outlets (Nijssen and Douglas 2008), or consumers' opinion on ethical trade and obstacles in FT consumption (Uusitalo and Oksanen 2004). The other studies reviewed in this subcategory use simple item measures to gather survey data on respondent's self-reported behavior or behavioral intention regarding FT consumption. Researchers are interested in the annual amount spent on FT products by respondents (De Pelsmacker and Janssens 2007), or inquire about the frequency of respondents' FT 
purchases (Doran and Natale 2011; Goig 2007). Ethical consumers' behavioral intention is also surveyed using items such as "The next time you go grocery shopping how likely are you to purchase a fair trade product?" (OzcaglarToulouse et al. 2006, p. 513; Shaw et al. 2000, p. 893; Kim et al. 1999, p. 213) or "How strong is your intention to avoid purchasing an item of sweatshop clothing the next time you shop for clothing?" (Shaw et al. 2006b, p. 432f.; item slightly modified in Shaw et al. 2007, p. 34). In addition to surveying respondents past purchasing behavior, Tanner and Kast (2003, p. 899) use the statement "I would be willing to pay a higher price to support small growers from third-world countries" with a five-point response scale (from 'strongly agree' to 'strongly disagree') to elicit respondents' WTP.

Respondents might answer such simple item measures on their ethical consumption intention or behavior in a socially desirable manner, leading to an overestimation of FT consumption in conventional surveys. Auger and Devinney (2007) argue that-from a methodological point of view - the gap between stated and actual buying behavior is caused by unconstrained survey response methods. When answering simple survey questions about their attitudes toward FT or their FT purchasing habits, respondents do not have any incentive to give truthful answers. Incentive-compatible research instruments that force respondents to reveal their 'true' preferences, attitudes and intentions are therefore to be preferred in research on ethical consumption (Auger and Devinney 2007).

Contingent Valuation Method An initial step to reduce the social desirability bias is the construction of hypothetical markets in surveys. Contingent valuation (CV) is a stated preference method that has been used in environmental economics to elicit willingness to pay for nonmarket public environmental goods (see Carson and Hanemann 2005 for an overview). Compared to revealed preference methods which use observed market behavior to elicit WTP, in CV respondents are directly asked for monetary values of these goods.

In this review, four studies use $\mathrm{CV}$ instead of simple item measures to elicit consumers' WTP (Becchetti and Rosati 2007; Hertel et al. 2009; Loureiro and Lotade 2005; Trudel and Cotte 2009). Differences between conventional and FT products are described in detail and survey respondents are asked for the maximum amount they would be willing to pay for ethical products. Different strategies of implementing CV in surveys, and the advantages and disadvantages of various question formats (e.g., open-ended questions, bidding game, payment card and payment ladder formats, dichotomous choice questions), have been discussed in the literature (Bateman et al. 2002, p. 135ff.; Carson 2000). Eliciting WTP for FT coffee, Loureiro and Lotade (2005, p. 133), for example, use a payment card format with bidding intervals in ten-cent increments ranging from 0 cents/lb to more than 81 cents/ $\mathrm{lb}$, and ask respondents:

Suppose that in order to buy fair trade, shade grown coffee, or organic coffee, you have to pay a premium over the regular coffee price $(\$ 6.5 / \mathrm{lb})$. Indicate below how much of a premium (if any) you would be willing to pay for the different types of coffee. I would like to remind you that it is perfectly fine if you are not willing to pay any premium, given that paying EXTRA for any of these coffees will leave you with less disposable income for other products or savings.

\section{Experiments}

Conjoint Analyses and Choice Experiments The basic idea behind conjoint analysis (CA) and choice experiments (CE) is that public and private goods can be described as a bundle of different product attributes; each combination of these characteristics results in a different product, and survey respondents are asked to evaluate these changes (Hanley et al. 1998). ${ }^{5}$ Product price and ethical features (e.g., FT label) are two possible product attributes amongst others. As in studies using CV, a hypothetical market of goods is constructed. But in contrast to CV methods-and to simple item survey questions for that matter-consumers' WTP is measured indirectly and respondents are forced to make trade-offs between the different product attributes. Thus, consumer choices are supposed to be more realistic and therefore yield more valid measures of WTP. The experimental design of $\mathrm{CA}$ and $\mathrm{CE}$ allows researchers to estimate the effect of each product attribute on respondents' product evaluations or product choices independently.

Four studies in this review use CA to investigate ethical consumption behavior. While Cranfield et al. (2010), De Pelsmacker et al. (2005a) and Dickson (2001) include a price attribute in their description of ethical products to estimate respondents' WTP, De Pelsmacker et al. (2005b) use CA to assess the relative importance of different marketing strategies of ethically labeled coffee, without including product price. ${ }^{6}$ In general price, FT and organic

\footnotetext{
5 Theoretically, CA and CE are based on Lancaster's (1966) 'Characteristics Theory of Value' in combination with the 'Random Utility Theory' (Hanley et al. 1998). See Louviere et al. (2000) for a discussion of theoretical and empirical implications.

${ }^{6}$ Therefore, we categorized the study by De Pelsmacker et al. (2005b) within the attitude-based framework, while the studies by De Pelsmacker et al. (2005a) and Dickson (2001) which include a price attribute and explicitly aim at eliciting consumers' WTP was located within the preference-based framework.
} 
label, country of origin, type of coffee beans and roast are product attributes which are often included in these studies. Basu and Hicks (2008) as well as Auger et al. (2003) draw on CE to estimate WTP for FT coffee and sweatshop-free manufactured athletic shoes. CE are also used to assess respondents' interest in different criteria for social labels (Howard and Allen 2010) and to analyze the effect of social context on FT consumption (Carlsson et al. 2010).

Laboratory Experiments Stated preference methods describing hypothetical markets in surveys have not remained uncontested. List (2003) argues that survey respondents in general have few incentives to reveal their preferences. Calling this divergence between hypothetical and actual statements 'hypothetical bias' (p. 193f.), List is in favor of simulating markets in laboratory experiments where participants make real purchasing decisions within an environment controlled by the researcher. Random assignment of participants to different experimental conditions makes it possible to investigate causal relationships between competing explanatory concepts.

Laboratory experiments are used to investigate the effect of product information transmitted via social labels on participants' product likeability (Grankvist et al. 2007; Poelman et al. 2008) and to assess participants WTP for FT products via product auctions (Didier and Lucie 2008; Rousu and Corrigan 2008; Hustvedt and Bernard 2010; Rode et al. 2008).

Natural Field Experiments In natural field experiments (see Harrison and List 2004 for a classification of experiments), participants are not aware of taking part in the experiment as their purchasing behavior is studied in real markets. Using such a method makes it possible to investigate consumers' revealed preferences for FT products from observing individual ethical consumption behavior. Although natural field experiments are highly incentive compatible and are seen as the best method for testing causal propositions (Levitt and List 2007; Reiley and List 2008), their drawback is that consumers' dispositions toward FT issues cannot be measured since it is only their actual buying behavior that is examined.

Two of the three studies in this subcategory investigate the effect of relative changes in product price on ethical consumption. In cooperation with a coffee vendor at a Canadian university campus, the relative prices for cups of FT and conventional coffee are experimentally adjusted (Arnot et al. 2006) and, in a department store, product prices between two racks of conventional and sweatshopfree manufactured athletic socks are manipulated (Prasad et al. 2004). The third natural field experiment investigates different marketing strategies for ethical consumption using a commercial stand that sells FT products at a Canadian university campus (d'Astous and Mathieu 2008).

Study Population in Research on Fair Trade

Consumption

Sample Types

Whether results on individual FT consumption can be generalized beyond the immediate context of a study depends on the type of respondent sample that researchers use. As can be seen from Table 3, few studies base their analyses on probability samples of the general population at national level (Carlsson et al. 2010 for Sweden; Dickson 2001 and Hertel et al. 2009 for the USA; Goig 2007 for Spain; Howard and Allen 2010 for the USA; Uusitalo and Oksanen 2004 for Finland) or municipal level (Tanner and Kast 2003 for the city of Bern, Switzerland). Most studies use non-probability samples such as convenience $(n=30)$, purposive $(n=7)$ or quota samples $(n=2)$.

Convenience samples feature prominently in research on FT consumption due to the high number of experimental studies (see column 4 in Appendix). These studies mostly rely on university students and academic staff (d'Astous and Mathieu 2008; Arnot et al. 2006; Auger et al. 2003; De Pelsmacker et al. 2005a, b; Grankvist et al. 2007; Hustvedt and Bernard 2010; Rode et al. 2008) or customers in grocery stores and shopping malls (Cranfield et al. 2010; Basu and Hicks 2008; Didier and Lucie 2008; Poelman et al. 2008; Prasad et al. 2004; Rousu and Corrigan 2008). Since

Table 3 Samples used in studies on Fair Trade consumption

\begin{tabular}{llr}
\hline Sample characteristics & Type of sample & $N$ \\
\hline Probability sample $^{\mathrm{a}}$ & National & 6 \\
& Municipality & 1 \\
Non-probability sample & & \\
Convenience & Shoppers & 20 \\
& University staff/students & 10 \\
Purposive & Fair Trade consumers & 7 \\
Quota & National & 2 \\
Total & & 46 \\
\hline
\end{tabular}

Notes: Of the 51 publications included in this review, 46 original samples can be identified. Galarraga and Markandya (2004) use the hedonic approach method and thus do not have any respondent sample, while the publications by Doran $(2009,2010)$, Varul (2009, 2010), and Shaw et al. $(2000,2006 \mathrm{~b}, 2007)$ are each based on the same respondent sample. Shaw and Newholm (2002) use the same respondent sample as Shaw and Clarke (1999). Goig (2007) uses two different respondent samples in his study

a Includes simple random, systematic random, and stratified samples of the general population

b Includes shoppers in general and shoppers of Fair Trade products only 
their primary aim is to test general propositions about individual FT consumption, probability samples are not necessary. Yet, general statements about the exact amount of money consumers are willing to pay for ethical product features or the prevalence of FT consumers in a given population cannot be made based on studies that use nonprobability samples.

Purposive samples of ethical consumers are almost exclusively used by studies drawing on qualitative methods (Carrigan et al. 2004; Nicholls and Lee 2006; Shaw et al. 2000, 2005, 2006b, 2007; Shaw and Clarke 1999; Shaw et al. 2006a; Shaw and Newholm 2002; Varul 2009, 2010). As these studies are often exploratory in nature or attempt to reconstruct ethical shopping behavior within everyday contexts, accentuated samples are needed. Therefore, researchers purposefully select participants who exhibit high levels of ethical consumerism, for example, members of the Scottish Co-operative Society (Shaw et al. 2005) or subscribers to the 'Ethical Consumer' magazine (Shaw and Clarke 1999).

\section{Country of Origin}

The geographical scope of research on FT consumption is in part determined by the location of researchers selecting respondents. In this review, we have only included journal articles published in English. Therefore, we may not provide a comprehensive picture of the geographical extent of current research on individual consumption of FT products as studies published in other languages might cover additional study locations.

Nevertheless, it is worth noting that individual FT consumption has been studied intensely in North America $(\mathrm{USA}=15 ;$ Canada $=4)$ and the United Kingdom

Table 4 Respondents' country of origin in studies on Fair Trade consumption

Notes: The publications by Doran (2009, 2010), Varul $(2009,2010)$, and Shaw et al. $(2000,2006 \mathrm{~b}, 2007)$ are each based on the same respondent sample. Shaw and Newholm (2002) use the same respondent sample as Shaw and Clarke (1999). For these studies, the country of origin is counted only once. Six studies (Auger et al. 2003; Basu and Hicks 2008; Kim et al. 2010; Littrell et al. 2005; Poelman et al. 2008; Varul 2009, 2010) combine respondent samples from two different countries $(n=13)$. Table 4 also shows that empirical research in Europe clusters in France $(n=4)$, Belgium $(n=3)$, Germany $(n=2)$, the Netherlands $(n=2)$, Spain $(n=2)$, and Sweden $(n=2)$. As sporadic studies show, FT consumption has also been investigated in Finland, Italy, and Switzerland. The studies by Auger et al. (2003) and Kim et al. (2010) using respondents from Australia and Hong Kong, and the USA and South Korea, respectively, combine the only samples located outside Europe and North America.

Five studies combine respondent samples from two different countries (see column 5 in Appendix). Varul $(2009,2010)$ studies differences in the ethical consumption practices of German and British respondents, while Kim et al. (2010) explore cultural differences in FT brand loyalty of university staff and students in the USA and South Korea. Poelman et al. (2008) investigate the influence of product information on FT pineapples between British and Dutch consumers. Basu and Hicks (2008) compare consumers' WTP for FT coffee across German and US respondents. The remaining two studies (Auger et al. 2003; Littrell et al. 2005) use samples from two countries without reporting cross-national comparisons.

\section{Selected Results ${ }^{7}$}

\section{Consumers' WTP}

Studies investigating consumers' preferences for FT products find empirical evidence of positive WTP for such products. Although product price is found to have a negative influence on respondents' purchasing decisions (Cailleba and Casteran 2010; Carlsson et al. 2010; Cranfield et al. 2010; Basu and Hicks 2008; Dickson 2001; Prasad et al. 2004), some respondents are willing to pay an ethical premium between US\$ 0.22/lb and US\$ $1.79 / \mathrm{lb}$ for FT coffee (Carlsson et al. 2010; De Pelsmacker et al. 2005a; Hertel et al. 2009; Loureiro and Lotade 2005; Trudel and Cotte 2009). For the coffee market in the UK, Galarraga and Markandya (2004) calculate that FT and organic labels increase the price of coffee by $11 \%$. In addition, the findings from Arnot's et al. (2006) natural field experiment suggest that Canadian students and academic staff buying FT coffee are less price sensitive than those buying conventional coffee. FT consumers in France seem to buy FT coffee rather irregularly and temporarily, indicating low brand loyalty (Cailleba and Casteran 2010). In the studies included in this review, the ethical premium for FT chocolate ranges between US\$ $0.10 / 3.5 \mathrm{oz} \quad(0.07 € / 100 \mathrm{~g}$, Rousu and Corrigan 2008) and US\$ 0.78/3.5 oz $(0.61 € / 100 \mathrm{~g}$, Didier

\footnotetext{
${ }_{7}$ Summarizing the results of the studies included in this review, we have to keep in mind that generalization of empirical findings is limited.
} 
and Lucie 2008). Auger et al. (2003) calculate $\$ 10.29$ as the ethical premium that respondents are willing to pay for athletic shoes manufactured without child labor.

\section{Consumer Attitudes, Motivations, and Values}

Consumer Attitudes Within the social psychological framework of consumers' attitudes, motivations, and values, the role of product price has been investigated with regard to respondents' perceived obstacles to and difficulties in buying FT products. Empirical evidence is mixed as some respondents' purchasing intentions for FT products have been found to be constrained by the lack of ethical product alternatives or difficulties finding them, by the lack of information about them, their higher product price (Shaw et al. 2006b; Uusitalo and Oksanen 2004), and distance needed to travel to a retail outlet (Becchetti and Rosati 2007), while for other respondents shopping inconvenience in general (De Pelsmacker and Janssens 2007) or product price in particular (Tanner and Kast 2003) do not have any effect on their buying intentions or self-reported buying behavior.

For Ajzen's TPB as a whole, empirical research shows that its explanatory power with regard to FT consumption is increased when the concepts of self-identity and ethical obligation are included in the model (Ozcaglar-Toulouse et al. 2006; Shaw et al. 2000). For respondents rarely buying FT products, ethical obligation and subjective norm both influence buying intentions, while for respondents often buying FT products, it is their positive assessment of that behavior, their perceived behavioral control (PBC), and their self-identity as ethical consumers that exert a positive effect (Ozcaglar-Toulouse et al. 2006). In addition, Shaw et al. (2000) find that the influence of subjective norm decreases when PBC is added to the empirical model. These findings are in line with evidence presented by Armitage and Conner (2001), suggesting that in general the construct of subjective norm is a weak predictor of intentions while PBC enhances the explanatory power of the TPB. Regarding sweatshopfree apparel, Shaw et al. (2007) show that the integration of desire in terms of volitional processes significantly improves Ajzen's basic model. Their empirical evidence suggests that desire as a personal motivation to avoid purchasing clothes manufactured in sweatshops, influenced by a negative assessment of buying such apparel, is needed in order to form a behavioral intention to avoid such clothes.

So far, such large-scale empirical research on further modifications of Ajzen's TPB with regard to the concepts of neutralization and belief formation is lacking. Yet, preliminary results can be drawn from in-depth interviews and focus group discussions in the UK. Here, respondents do indeed use neutralization techniques to excuse the purchase of conventional products (Chatzidakis et al.
2007). Participants' beliefs with regard to ethical consumption are formed by various normative and broader environmental factors such as family and friends, ethical organizations, and religion (Shaw and Clarke 1999).

With regard to consumer attitudes in general, socially responsible attitudes (Kim et al. 1999), support of human rights (Hertel et al. 2009) and a need for self-uniqueness (Halepete et al. 2009) among female FT apparel shoppers in the USA, combined with an increased consciousness for the global dimension of consumption, have been found to positively influence FT consumption. Spanish respondents consuming FT products are found to exhibit a higher level of global cognitive orientation, which is mediated by their trust in international NGOs and their sense of social responsibility (Goig 2007); Dutch respondents with a favorable image of FT stores are found to be more socialminded and world-minded (Nijssen and Douglas 2008).

Information and Communication There is mixed evidence on the influence of social labels on FT consumption. Information transmitted via FT labels hardly influence product likeability (Grankvist et al. 2007; Poelman et al. 2008) and mispurchases due to inadequate labeling prevail even after additional information has been given (Rousu and Corrigan 2008). Yet, Howard and Allen (2010) find that when asked in a nationwide survey in the USA, around $80 \%$ of respondents said they are interested in product labels and $75 \%$ showed an interest in brochures or retail displays as sources of product information. When asked about product labeling criteria, respondents ranked 'locally grown within 50 miles of the point of purchase' and 'humane treatment of animals' highest, followed by 'decent living wages for workers.' Belgian respondents' purchase intentions are highest for coffee labeled 'Fair Trade' and certified by the European Union (De Pelsmacker et al. 2005b). Studies investigating the effect of social labels on consumers' WTP find evidence that official FT labels positively affect the amount of money respondents are willing to pay extra for ethical product features (Basu and Hicks 2008; Dickson 2001; Didier and Lucie 2008; Hustvedt and Bernard 2010).

In terms of strategies in product marketing, the natural field experiment by d'Astous and Mathieu (2008) shows that contrary to the researchers' expectations, abstract information rather than specific information about the living conditions of small-scale producers lead on average to higher mean spending amounts for FT products. Results from focus group discussions in the UK (Nicholls and Lee 2006; Wright and Heaton 2006) suggest that creating brand images for FT products might increase consumer commitment to buy such products.

Consumer Values A diverse set of consumer values seems to guide respondents' FT consumption practices. US 
consumers of FT products score high on Schwartz's universalism values (Doran 2009, 2010), while ethical consumers in the UK (Shaw et al. 2005) and France (de Ferran and Grunert 2007) are guided by hedonism, equality, and self-direction values. In their lab experiment, Grankvist et al. (2007) find that Swedish participants exhibiting the value 'warm relationships with others' rated the taste of ecoand FT labeled orange juice higher. In the USA, there is only a weak link between religion and intentions to consume FT products (Doran and Natale 2011). Ethical consumption values are found to directly influence FT brand loyalty for Starbucks coffee among US and South Korean academic staff and university students (Kim et al. 2010).

\section{Consumer Identity}

As Table 2 indicates, sociological research on personal FT identity has largely been qualitative in nature. In-depth interviews with a small number of ethical consumers from the UK suggest that participants use the metaphor of 'consumption as economic voting' to locate their purchasing behavior of FT products as active engagement within the political sphere of consumer society (Shaw et al. 2006a). By the same token, tentative conclusions about the construction of consumers as moral persons in the UK and Germany have been drawn. Varul (2010) finds evidence that the purchase of FT products reassures interviewees' selfimage as 'morally good' which has to be built up to counteract their hedonistic consumerist desires. FT consumption is a means of expressing important features of interviewees' personality and dissatisfaction with consumer society. In terms of cultural differences, British interviewees placed more emphasis on individual choice and taste which they can express by consuming FT products while their German counterparts see FT consumption more in terms of consumer choices guided by FT certification institutions (Varul 2009). A content analysis of British consumers' autobiographical writings to the Mass Observation Archive reveals that respondents see FT consumption as a means of expressing their commitment to act as morally good persons (Adams and Raisborough 2010). Shaw and Newholm (2002) find that purchasing FT products is seen as a means to achieve more sustainable consumption patterns by choosing ethical alternatives instead of reducing consumption levels in response to ethical concerns. For their interviewees, FT consumption is one way to present the morality of their lifestyle and to secure their integrity.

In summary, categorizing the 51 articles included in this review according to their key research objective reveals that research on individual FT consumption has mainly concentrated on consumers' attitudes and motivations and the contexts in which they are formed and, to a lesser extent, on consumers' preferences and the elicitation of WTP for ethical products. Studies draw on several explanatory concepts from social psychology and sociology rather than economic explanations; it is Ajzen's TPB with regard to consumer attitudes and-to a lesser extentinformation and communication as social labeling that features prominently among scholars. Qualitative methods and surveys based on consumers' self-reported behavior are mainly applied in studies analyzing consumers' attitudes, motivations, and values.

Studies concentrating on consumers' ethical preferences mostly rely on experimental designs. Using methods that increase consumers' incentives to reveal their preferences for ethical products, researchers have primarily elicited consumers' WTP in hypothetical markets employing contingent valuation, conjoint analyses, and choice experiments. Less frequently, markets are simulated in lab experiments via product auctions. Few studies set up natural field experiments in real markets to study FT consumption.

With regard to the study populations used in research on individual FT consumption, it is non-probability convenience samples of shoppers as well as university students and academic staff that prevail over national probability samples of consumers. Furthermore, the majority of respondents tend to be from the UK, USA, and Canada.

As with most categorizations in the social sciences, the distinction we make between consumer preferences and consumer attitudes in terms of key research objectives - and subsequently theoretical approaches and methods-is not always clear cut. Our review of current research into individual FT consumption leads us to identify three intersecting aspects regarding the two principal research objectives. First, product price is - in addition to consumers' budget restriction - the key explanatory factor in economic approaches to FT consumption. Eliciting consumers' WTP is the main research objective of such studies. This, however, does not imply that studies drawing on social psychological or sociological approaches ignore the price of FT products altogether. Product price is one explanatory factor amongst others and analyzed in terms of difficulties and obstacles that consumers might encounter when buying FT products. Second, information and social labeling are mostly analyzed with regard to consumer attitudes and motivations, leaving aside the effect FT labels might have on consumers' WTP. Studies explicitly investigating such an effect draw on economic explanations within a preference-based research objective. Third, experimental designs are most often used in studies investigating consumers' WTP for FT products, revealing a close affinity to environmental and transport economics. Yet, there are several studies which investigate FT consumption from a marketing perspective that also use experiments and implicitly draw on economic explanations for FT consumption. 
Assessing the Current State of Research on Fair Trade Consumption

We have identified the following eight problems of current research on individual FT consumption concerning theory as well as methods: (i) missing links between key research objectives, (ii) studies with narrow theoretical perspectives, (iii) ad-hoc arguments and lack of theoretical reasoning, (iv) unclear assumptions and ignoring conflicting hypotheses, (v) causality, (vi) measuring an individual's consumption behavior, (vii) generalizability of empirical findings, and (viii) cultural bias in FT research.

\section{Missing links Between Key Research Objectives}

With regard to theory, our review suggests that preferencebased approaches in economics on the one hand and attitude- and motivation-based approaches in social psychology or sociology on the other hand are rarely interconnected. This might be due to the fact that economic, social psychological and sociological studies are based on different persuasions regarding theory development and typically employ different methods to study FT consumption. Experiments and stated preference methods are mostly used in studies drawing on economic approaches whereas studies relying on social psychological and sociological arguments mainly use conventional surveys and qualitative methods. In economics it is still rather unusual to test theoretical models using questionnaire data. Unlike conventional surveys, revealed and stated preference methods such as hedonic pricing methods and choice experiments have a clear theoretical foundation inherent to these methods. Following, for example, welfare economics and random utility theory, researchers assume utility maximizing behavior, given certain behavioral restrictions such as an individual's disposable income, and thus focus on stated or revealed behavioral responses.

\section{Narrow Theoretical Perspectives}

The theoretical foundation of stated and revealed preference methods might explain why studies drawing on economic explanations tend to have a rather narrow theoretical focus. Although the assumptions of utility theory are not tested directly and are often contested, economic approaches are based on a formalized axiomatic theory which is often lacking in social psychological and sociological studies. Yet, studies relying on economic explanations tend to neglect important behavioral determinants such as values and norms which can be considered relevant in the context of FT consumption (e.g., Arnot et al. 2006; Basu and Hicks 2008; Cranfield et al. 2010; Didier and Lucie 2008; Galarraga and Markandya 2004; Prasad et al. 2004;
Rode et al. 2008; Rousu and Corrigan 2008). Compared to studies relying on economic approaches, most social psychological studies analyze individual FT consumption using survey data that capture values, attitudes, or norms (in addition to economic factors such as income). Although their theoretical focus seems to be much broader, our review suggests that in the end most studies refer to a small set of recurring and well-known behavioral models such as Ajzen's TPB. Most sociological studies included in the present review do only marginally account for the growing quantitative research on sustainable consumption and (green) consumer identity that has emerged within environmental sociology and social psychology (see Soron 2010 for an overview). Complementary theories focusing on social capital (Putnam 1993; Portes 1998), justice principles (Deutsch 1975; Miller 1992), social identity (Tajfel and Turner 1986) and altruistic behavior (Andreoni 1990; Schwartz 1977) are rarely taken into account in empirical research on FT consumption. ${ }^{8}$ Considering these theoretical approaches might be useful because they point to relevant concepts such as 'trust in (FT) institutions,' 'perceived fairness of economic structures,' 'in- and outgroup bias' and 'norm-activating factors.'

\section{Ad-Hoc Arguments and Lack of Theoretical Reasoning}

Our review includes studies that propose explanatory factors but derive behavioral expectations in a rather ad-hoc manner. For example, Dickson (2001), Littrell et al. (2005) or Wright and Heaton (2006) propose determinants of FT consumption which are not linked to in-depth theoretical discussions. Studies geared towards explaining individual FT consumption should offer sound theoretical arguments instead of solely introducing ad-hoc determinants.

\section{Unclear Assumptions and Ignoring Conflicting Hypotheses}

As has already been pointed out, extensions and modifications of Ajzen's TPB have dominated social psychological research on FT consumption to date. This research strategy is problematic for two reasons: First, most studies do not clarify how the newly introduced factors are related to the original theoretical model. The TPB, for instance, is based on subjective expected utility theory as used in sociological and social psychological research (Opp 1999). This raises the question as to whether these underlying calculative behavioral processes can also be assumed for determinants

\footnotetext{
8 The study by Basu and Hicks (2008) is an exception in that it is geared towards investigating how respondents' WTP for FT coffee is affected by respondents' aversion to poverty and inequality due to the scope of Fair Trade programs.
} 
such as 'ethical obligation' which are introduced with reference to concepts such as identity and norms (e.g., Chatzidakis et al. 2007; Ozcaglar-Toulouse et al. 2006; Shaw et al. 2000). Second, extending existing theories might neglect conflicting theoretical hypotheses following from other theories. For example, Schwartz's norm-activation theory (Schwartz 1977) would suggest several moderating variables until a personal norm (e.g., an ethical obligation) leads to corresponding behavior. Thus, before integrating and extending theories, it seems to be necessary to compare different theories in a competitive manner; effects of single determinants might change or even diminish when other rival explanatory factors are considered.

\section{Causality}

Another aspect of testing theories with regard to FT consumption is the question of causality. Based on cross-sectional survey data which are often used in this field of research, it is difficult to clarify, for example, whether (a) an attitude towards FT determines behavioral intentions and behavior, (b) intentions and behavior determine an attitude, or (c) a mere correlation between attitude and behavior is present. Experiments employing a 'before-and-after' design such as natural field experiments and panel data can help to detect causal relations proposed by theories.

\section{Measuring an Individual's Consumption Behavior}

An inappropriate measurement instrument might lead to misleading conclusions. Obviously, a hypothetical bias-the gap between stated and actual behavior-would result in an overestimation of prospective market shares. Arguing from a methodological perspective, studies relying on economic explanations of individual FT consumption are based on more reliable measures of consumption behavior since experiments, for instance, are more incentive compatible than simple item measures in surveys (Auger and Devinney 2007). ${ }^{9}$ Studies relying on social psychological approaches to explain individual FT consumption might be affected by social desirability and, hence, untruthful responses are more likely since our review shows that most of these studies rely on conventional surveys without making use of incentivecompatible methods such as choice experiments.

\footnotetext{
${ }^{9}$ In contrast to this methodological approach to the attitude-behavior gap, Carrington et al. (2010) argue for a conceptual model that accounts for the insights gained into social psychological research on consumer behavior: "Our conceptual model is based on the assumption that contextual elements may assist to explain the gap between purchase intentions and actual purchase behavior. Hence, these elements are integrated into the cognitive intention-behavior framework to develop a holistic conceptual model of ethical consumer behavior." (p. 143).
}

\section{Generalizability of Empirical Findings}

The studies included in this review almost exclusively measure attitudes or behavioral intentions regarding FT consumption (exceptions are De Pelsmacker and Janssens 2007; Shaw et al. 2006b). Thus, in a strict sense, conclusions can only be drawn for these concepts, but not for the behavior of interest. Compared to conventional surveys, laboratory and field experiments comprise a better measurement of behavioral intentions and behavior, yet they are more likely to lack external validity.

In addition, our review suggests that the overwhelming majority of studies on FT consumption are based on convenience and purposive samples. Often participants are university students and academic staff, or customers in shopping malls. Thus, it is not possible to generalize empirical findings beyond the immediate study context, a fact which tends to be neglected when discussing empirical findings (e.g., Littrell et al. 2005; Loureiro and Lotade 2005; Trudel and Cotte 2009)_also regarding studies which take qualitative approaches (e.g., Nicholls and Lee 2006; Wright and Heaton 2006). Large-scale studies that use national samples are rare and, hence, are needed more often in future research. However, compared to small-scale laboratory and field experiments, it is much more difficult to implement incentive-compatible measures of FT consumption intentions and behavior in large-scale surveys. This problem can partly be solved by using experimental methods such as choice experiments in large-scale surveys and by conducting systematic research that combines different methods in a cumulative manner (e.g., combining conventional surveys and field experiments). Thus, conclusions can be drawn concerning both the external validity of small-scale studies and the hypothetical bias that is more likely to be present in survey data. Ideally, this means that not only different theories but also the results of different methods regarding one and the same type of FT consumption behavior (e.g., purchase of FT coffee) should be compared. None of the studies included in this review follows this research strategy.

\section{Cultural Bias}

Finally, research on FT consumption is prone to a 'cultural bias.' Our review shows that most studies are carried out in the USA, UK, and Canada. The prevalence of FT consumers within a given country might not be generalizable to other countries. Country-specific market structures, cultural traits and other path dependencies might matter for individual consumption decisions. Yet, research on these issues is scarce. One indicator for such cross-country differences is the market share which varies considerably 
between Western countries. ${ }^{10}$ As large scale comparative studies on individual FT consumption practices are rare, ${ }^{11}$ it is not at all clear whether results obtained from Englishspeaking countries in North America and Europe, for instance, equally apply to other affluent societies. Researchers should thus be aware that their findings are not necessarily transferable to all markets in the global North.

\section{Advancing Research on Fair Trade Consumption}

Compared to other fields of research on ethical decision making (see Ford and Richardson 1994 as well as O'Fallon and Butterfield 2005 for an overview), scholars are only just beginning to understand and explain individual FT consumption. We suggest two steps to be taken in theoretical discussions and methodological applications to advance research on FT consumption.

First, studies to date either employ an economic approach that is concerned with consumer preferences and measurements of WTP, a social psychological approach or a sociological approach which are concerned, inter alia, with consumer attitudes, values and identity. Studies typically draw on a single theory or extend an existing theory to explain the expression of attitudes, behavioral intention or the behavior itself. Future research on FT consumption would benefit from a broader theoretical perspective and comparisons of different theories in a competitive manner. This would help to clarify under what conditions certain determinants and theories are more successful in explaining FT consumption than others. In addition, divergent implications resulting from different theories (e.g., norm-related theories would suggest behavioral mechanisms quite different from those proposed by theories focusing on monetary restrictions) can be taken into account when applying such a comparative perspective of theory testing. In addition, studies investigating the causal relations proposed by theories are needed. In order to detect causality, field experiments can be considered to be an appropriate method.

\footnotetext{
${ }^{10}$ For example, within Europe, the market share of FT bananas in 2007 varied between 1.5\% in Ireland and 55\% in Switzerland (Krier 2008, p. 46).

11 To our knowledge, there are two large-scale studies investigating cross-cultural differences in consumer ethics. Using best-worst scaling methodology, Auger et al. (2007) analyze differences in respondents' attitudes towards social and ethical issues (e.g., animal rights, human rights, no child labor) across six countries (Germany, Spain, Turkey, USA, India, and South Korea), finding higher than average ratings with regard to human rights, use of child labor, safe and good working conditions across all countries. Drawing on empirical findings from in-depth interviews with 160 consumers from eight different countries (Australia, China, Germany, India, Spain, Sweden, Turkey, and the USA), Belk et al. (2005) argue that there is a general lack of concern for ethical issues in consumption regardless of the country of origin. As these studies do not focus on FT consumption in particular, they have not been included in this review.
}

Moreover, researchers should evaluate their theories under consideration. In current research, especially in social psychological studies, the explanatory power of a theory tends to be equated with the explained variance in statistical models (e.g., De Pelsmacker and Janssens 2007; Doran 2009; Littrell et al. 2005; Ozcaglar-Toulouse et al. 2006; Shaw et al. 2007, 2000; Tanner and Kast 2003). This might not be the only criterion for a 'good' theory and explanation. For example, proposed relations such as 'a positive attitude towards behavior $x$ increases the likelihood of observing a behavioral intention towards $x$ ' might be classified as trivial and somewhat tautological. Thus, research on FT consumption needs a much more theory-based discussion.

Second, incentive-compatible measures of FT consumption intentions and behavior should be used in empirical studies whenever possible. From a methodological point of view, incentive-compatible measures of FT consumption behavior in experiments are to be preferred to simple item measures. This is primarily relevant to conventional survey research as question formats similar to choice experiments or contingent valuation seem to be promising alternatives. Such formats should also lower the likelihood of untruthful responses in general and socially desirable responses in particular. Moreover, they can be expected to lower the hypothetical bias-the well-known gap between stated and actual behavior. From a broader perspective, research on FT consumption can certainly be improved by taking up a cumulative research strategy as discussed currently in behavioral and experimental economics, (e.g., Levitt and List 2007) and put forward by Auger and Devinney (2007, p. 378) as well as Carrington et al. (2010, p. 153) in the context of ethical consumption research. In addition to competitively comparing theories, this would imply using different methods such as population surveys, laboratory and field experiments to study one and the same type of FT consumption behavior. This strategy might contribute to estimating the extent of the hypothetical bias, for example, in terms of calibrating individuals' WTP. Moreover, it allows for testing the external validity of small-scale studies such as laboratory and field experiments. Regarding the external validity of research on FT consumption in general, there is a need for additional cross-national studies that consider differences in market structures and cultural traits, and try to assess the extent of a 'cultural bias' in this field of research.

Taken together, research on FT consumption would benefit from both a multiple-motives and a multiple-methods perspective facilitating a strict comparison of relevant theories, the uncovering of truthful responses, detection of causal relations, and generalization of empirical findings.

Open Access This article is distributed under the terms of the Creative Commons Attribution Noncommercial License which permits any noncommercial use, distribution, and reproduction in any medium, provided the original author(s) and source are credited. 


\section{Appendix}

See Table 5 .

Table 5 Empirical studies examining individual Fair Trade consumption

\begin{tabular}{|c|c|c|c|c|c|}
\hline Study & $\begin{array}{l}\text { Theoretical } \\
\text { approach }\end{array}$ & Method & Sample & Country & Selected results \\
\hline \multicolumn{6}{|c|}{ Key research objective } \\
\hline \multicolumn{6}{|c|}{ (1) Consumers' preferences and WTP for Fair Trade products } \\
\hline $\begin{array}{l}\text { Cailleba and } \\
\text { Casteran } \\
(2010)\end{array}$ & $\begin{array}{l}\text { Social psychology/ } \\
\text { marketing }\end{array}$ & $\begin{array}{l}\text { Househod panel } \\
\text { survey with } \\
\text { scanner data }\end{array}$ & Quota sample & $\mathrm{F}$ & $\begin{array}{l}\text { Brand loyalty towards FT coffee is } \\
\text { low among FT consumers. } \\
\text { Customers have become } \\
\text { temporary and sporadic buyers of } \\
\text { FT coffee. Product price exerts a } \\
\text { negative effect on the purchase } \\
\text { of FT coffee. }\end{array}$ \\
\hline $\begin{array}{l}\text { Carlsson et al. } \\
\text { (2010) }\end{array}$ & Economics & Choice experiment & Simple random & SWE & $\begin{array}{l}\text { Female participants' WTP for FT } \\
\text { coffee is positively influenced by } \\
\text { information about the } \\
\text { consumption choices of others }\end{array}$ \\
\hline $\begin{array}{l}\text { Cranfield et al. } \\
\text { (2010) }\end{array}$ & Economics & Conjoint analysis & Convenience & $\mathrm{CDN}$ & $\begin{array}{l}\text { Participants' purchase decision for } \\
\text { coffee is most strongly } \\
\text { influenced by price and FT label, } \\
\text { with product price having a } \\
\text { negative effect on respondents' } \\
\text { WTP }\end{array}$ \\
\hline $\begin{array}{l}\text { Hustvedt and } \\
\text { Bernard } \\
(2010)\end{array}$ & Economics & $\begin{array}{l}\text { Lab experiment with } \\
\text { simulated market }\end{array}$ & Convenience & USA & $\begin{array}{l}\text { Participants' WTP for apparel } \\
\text { increases when t-shirts are } \\
\text { labeled "sweatshop-free." } \\
\text { Positive attitudes toward social } \\
\text { responsibility and FT increase } \\
\text { participants' WTP }\end{array}$ \\
\hline $\begin{array}{l}\text { Trudel and } \\
\text { Cotte (2009) }\end{array}$ & Economics & $\begin{array}{l}\text { Contingent valuation } \\
\text { method }\end{array}$ & Convenience & USA & $\begin{array}{l}\text { Participants are willing to pay an } \\
\text { ethical premium of } \$ 1.40 / 1 \mathrm{~b} \text { for } \\
\text { FT coffee }\end{array}$ \\
\hline $\begin{array}{l}\text { Basu and Hicks } \\
\text { (2008) }\end{array}$ & Economics & Choice experiment & Convenience & $\mathrm{USA}+\mathrm{D}$ & $\begin{array}{l}\text { Price has a negative effect on } \\
\text { respondents' WTP for FT coffee. } \\
\text { WTP is influenced by their } \\
\text { preferences for poverty and } \\
\text { inequality aversion }\end{array}$ \\
\hline $\begin{array}{l}\text { Didier and } \\
\text { Lucie (2008) }\end{array}$ & Economics & $\begin{array}{l}\text { Lab experiment with } \\
\text { simulated market }\end{array}$ & Convenience & $\mathrm{F}$ & $\begin{array}{l}\text { Participants are willing to pay an } \\
\text { ethical premium of } 0.61 € / 100 \mathrm{~g} \\
\text { for FT chocolate }\end{array}$ \\
\hline $\begin{array}{l}\text { Rode et al. } \\
\text { (2008) }\end{array}$ & Economics & $\begin{array}{l}\text { Lab experiment with } \\
\text { simulated market }\end{array}$ & Convenience & ESP & $\begin{array}{l}\text { Participants are willing to pay an } \\
\text { ethical premium for goods } \\
\text { produced without child labor }\end{array}$ \\
\hline $\begin{array}{l}\text { Rousu and } \\
\text { Corrigan } \\
(2008)\end{array}$ & Economics & $\begin{array}{l}\text { Field experiment } \\
\text { with simulated } \\
\text { market }\end{array}$ & Convenience & USA & $\begin{array}{l}\text { Participants are willing to pay an } \\
\text { ethical premium of } \$ 0.10 \text { per } \\
3.5 \mathrm{oz} \text { for FT chocolate and } \\
\$ 0.24 \text { per } 2 \mathrm{lb} \text { for FT bananas }\end{array}$ \\
\hline $\begin{array}{l}\text { Becchetti and } \\
\text { Rosati (2007) }\end{array}$ & Economics & $\begin{array}{l}\text { Contingent valuation } \\
\text { method }\end{array}$ & Convenience & IT & $\begin{array}{l}\text { Respondents' average monthly } \\
\text { expenditure for FT products is } 20 \\
€ \text {. Awareness of FT criteria } \\
\text { positively influences their WTP } \\
\text { while purchase in supermarkets } \\
\text { and long distance to retailers } \\
\text { exert a negative influence }\end{array}$ \\
\hline
\end{tabular}


Table 5 continued

\begin{tabular}{|c|c|c|c|c|c|}
\hline Study & $\begin{array}{l}\text { Theoretical } \\
\text { approach }\end{array}$ & Method & Sample & Country & Selected results \\
\hline $\begin{array}{l}\text { Arnot et al. } \\
(2006)\end{array}$ & Economics & $\begin{array}{l}\text { Natural field } \\
\text { experiment in } \\
\text { university café }\end{array}$ & Convenience & $\mathrm{CDN}$ & $\begin{array}{l}\text { Price exerts a negative effect on } \\
\text { the demand for FT coffee, yet } \\
\text { participants buying FT coffee are } \\
\text { less price sensitive than those } \\
\text { buying conventional coffee }\end{array}$ \\
\hline $\begin{array}{l}\text { De Pelsmacker } \\
\text { et al. (2005a) }\end{array}$ & $\begin{array}{r}\text { Economics/ } \\
\text { marketing }\end{array}$ & Conjoint analysis & Convenience & $\mathrm{BE}$ & $\begin{array}{l}\text { On average, participants are } \\
\text { willing to pay an ethical } \\
\text { premium of } 10 \%(0.19 € \text { per } \\
500 \mathrm{~g}) \text { for FT coffee }\end{array}$ \\
\hline $\begin{array}{l}\text { Loureiro and } \\
\text { Lotade (2005) }\end{array}$ & Economics & $\begin{array}{l}\text { Contingent valuation } \\
\text { method }\end{array}$ & Convenience & USA & $\begin{array}{l}\text { Respondents are willing to pay an } \\
\text { ethical premium of } \$ 0.22 / \mathrm{lb} \text { for } \\
\text { FT coffee }\end{array}$ \\
\hline $\begin{array}{l}\text { Galarraga and } \\
\text { Markandya } \\
(2004)\end{array}$ & Economics & Hedonic approach & - & UK & $\begin{array}{l}\text { Presence of FT/organic label } \\
\text { increases the price of coffee by } \\
11 \%\end{array}$ \\
\hline $\begin{array}{l}\text { Prasad et al. } \\
(2004)\end{array}$ & Economics & $\begin{array}{l}\text { Natural field } \\
\text { experiment in } \\
\text { department store }\end{array}$ & Convenience & USA & $\begin{array}{l}\text { Consumers' purchasing decision } \\
\text { for socks produced in accordance } \\
\text { with good working conditions } \\
\text { are dominated by product price }\end{array}$ \\
\hline $\begin{array}{l}\text { Auger et al. } \\
\text { (2003) }\end{array}$ & Economics & Choice experiment & Convenience & AUS + HK & $\begin{array}{l}\text { Respondents are willing to pay an } \\
\text { ethical premium of } \$ 10.29 \text { for } \\
\text { shoes produced without child } \\
\text { labor }\end{array}$ \\
\hline Dickson (2001) & $\begin{array}{l}\text { Social psychology/ } \\
\text { marketing }\end{array}$ & Conjoint analysis & Systematic random & USA & $\begin{array}{l}\text { Respondents' purchase intentions } \\
\text { for a shirt are positively } \\
\text { influenced by a no-sweatshop } \\
\text { label. Yet, price exerts a strong } \\
\text { negative effect }\end{array}$ \\
\hline \multicolumn{6}{|c|}{ (2) Consumers' attitudes and motivations toward Fair Trade products } \\
\hline $\begin{array}{l}\text { Doran and } \\
\text { Natale (2011) }\end{array}$ & $\begin{array}{l}\text { Social psychology: } \\
\text { consumer values, } \\
\text { religion }\end{array}$ & Survey & Convenience & USA & $\begin{array}{l}\text { Respondents' self-reported } \\
\text { frequency of buying FT products } \\
\text { is higher if they are Buddhist or } \\
\text { non-religious }\end{array}$ \\
\hline $\begin{array}{l}\text { Doran }(2009 \text {, } \\
\text { 2010) }\end{array}$ & $\begin{array}{l}\text { Social psychology: } \\
\text { SVT, consumer } \\
\text { values }\end{array}$ & Survey & Convenience & USA & $\begin{array}{l}\text { Respondents consuming FT } \\
\text { products rated universalism } \\
\text { values as most important }\end{array}$ \\
\hline $\begin{array}{l}\text { Adams and } \\
\text { Raisborough } \\
(2010)\end{array}$ & $\begin{array}{l}\text { Sociology: ethical } \\
\text { selving, consumer } \\
\text { identity }\end{array}$ & Content analysis & Convenience & UK & $\begin{array}{l}\text { Respondents show a commitment } \\
\text { to act as a morally good person } \\
\text { by purchasing FT products, yet } \\
\text { product price is perceived as the } \\
\text { most important purchasing } \\
\text { obstacle }\end{array}$ \\
\hline $\begin{array}{l}\text { Howard and } \\
\text { Allen (2010) }\end{array}$ & $\begin{array}{l}\text { Social psychology: } \\
\text { political } \\
\text { consumerism, } \\
\text { product } \\
\text { information via } \\
\text { social labels }\end{array}$ & Choice experiment & Simple random & USA & $\begin{array}{l}80 \% \text { of respondents prefer labels } \\
\text { as product information. } \\
\text { Respondents ranked local and } \\
\text { humane as the highest product } \\
\text { labeling criteria, followed by } \\
\text { decent living wages for workers }\end{array}$ \\
\hline $\begin{array}{l}\text { Kim et al. } \\
\text { (2010) }\end{array}$ & $\begin{array}{l}\text { Social psychology: } \\
\text { consumer values } \\
\text { and beliefs }\end{array}$ & Survey & Convenience & $\mathrm{USA}+\mathrm{ROK}$ & $\begin{array}{l}\text { Respondents' loyalty for FT } \\
\text { brands is positively influenced by } \\
\text { their ethical consumption values } \\
\text { mediated through FT product } \\
\text { belief and FT corporate } \\
\text { evaluation }\end{array}$ \\
\hline
\end{tabular}


Table 5 continued

\begin{tabular}{|c|c|c|c|c|c|}
\hline Study & Theoretical approach & Method & Sample & Country & Selected results \\
\hline $\begin{array}{l}\text { Varul (2009, } \\
\text { 2010) }\end{array}$ & $\begin{array}{l}\text { Sociology: ethical } \\
\text { selving, consumer } \\
\text { identity }\end{array}$ & $\begin{array}{l}\text { In-depth interviews } \\
\text { and content } \\
\text { analysis }\end{array}$ & Purposive & $\mathrm{UK}+\mathrm{D}$ & $\begin{array}{l}\text { Purchase of FT products reassures } \\
\text { interviewees' self-image as } \\
\text { morally good and expressing an } \\
\text { important feature of their } \\
\text { personality through ethical } \\
\text { consumption }\end{array}$ \\
\hline $\begin{array}{l}\text { Halepete et al. } \\
\text { (2009) }\end{array}$ & $\begin{array}{l}\text { Social psychology: } \\
\text { consumer attitudes in } \\
\text { product } \\
\text { personalization }\end{array}$ & Survey & Convenience & USA & $\begin{array}{l}\text { Respondents' need for self- } \\
\text { uniqueness positively influences } \\
\text { their attitudes towards FT apparel } \\
\text { and in turn their purchase } \\
\text { intentions for such clothes }\end{array}$ \\
\hline $\begin{array}{l}\text { Hertel et al. } \\
\text { (2009) }\end{array}$ & $\begin{array}{l}\text { Social psychology: } \\
\text { consumer attitudes }\end{array}$ & $\begin{array}{l}\text { Contingent valuation } \\
\text { method }\end{array}$ & Simple random & USA & $\begin{array}{l}62 \% \text { of respondents are willing to } \\
\text { pay } 5 \$ \text { extra for sweatshop-free } \\
\text { clothing and } 75 \% \text { of respondents } \\
\text { show WTP of } 50 \mathrm{c} / \mathrm{lb} \text { extra for FT } \\
\text { coffee. Support for human rights is } \\
\text { positively associated with WTP for } \\
\text { both products }\end{array}$ \\
\hline $\begin{array}{l}\text { d'Astous and } \\
\text { Mathieu } \\
(2008)\end{array}$ & $\begin{array}{l}\text { Social psychology/ } \\
\text { marketing: } \\
\text { information }\end{array}$ & $\begin{array}{l}\text { Natural field } \\
\text { experiment at } \\
\text { university }\end{array}$ & Convenience & $\mathrm{CDN}$ & $\begin{array}{l}\text { Participants' mean spending amoun } \\
\text { for FT products was higher when } \\
\text { abstract instead of specific } \\
\text { information about FT products was } \\
\text { given }\end{array}$ \\
\hline $\begin{array}{l}\text { Nijssen and } \\
\text { Douglas } \\
(2008)\end{array}$ & $\begin{array}{l}\text { Social psychology: } \\
\text { consumer attitudes as } \\
\text { world-/social- } \\
\text { mindedness }\end{array}$ & Survey & Convenience & NL & $\begin{array}{l}\text { Respondents with a favorable image } \\
\text { of FT stores are more social- } \\
\text { minded and world-minded }\end{array}$ \\
\hline $\begin{array}{l}\text { Poelman et al. } \\
(2008)\end{array}$ & $\begin{array}{l}\text { Social psychology/ } \\
\text { marketing: product } \\
\text { information via labels }\end{array}$ & Lab experiment & Convenience & $\mathrm{UK}+\mathrm{NL}$ & $\begin{array}{l}\text { Information about organic or FT } \\
\text { features of pineapples hardly } \\
\text { influences product liking or } \\
\text { perception }\end{array}$ \\
\hline $\begin{array}{l}\text { Chatzidakis } \\
\text { et al. (2007) }\end{array}$ & $\begin{array}{l}\text { Social psychology: } \\
\text { TPB, neutralization } \\
\text { mechanisms }\end{array}$ & In-depth interviews & Convenience & UK & $\begin{array}{l}\text { Interviewees show a range of } \\
\text { neutralization techniques (e.g., } \\
\text { denial of responsibility) to justify } \\
\text { not purchasing FT products }\end{array}$ \\
\hline $\begin{array}{l}\text { de Ferran and } \\
\text { Grunert } \\
(2007)\end{array}$ & $\begin{array}{l}\text { Social psychology: } \\
\text { consumer motives and } \\
\text { values }\end{array}$ & $\begin{array}{l}\text { Means-end chain } \\
\text { analysis }\end{array}$ & Convenience & $\mathrm{F}$ & $\begin{array}{l}\text { Respondents buying FT products } \\
\text { have quite different motives and } \\
\text { values (e.g., equality, hedonism, } \\
\text { protection of environment and own } \\
\text { health) }\end{array}$ \\
\hline $\begin{array}{l}\text { De Pelsmacker } \\
\text { and Janssens } \\
(2007)\end{array}$ & $\begin{array}{l}\text { Social psychology: } \\
\text { TPB, product } \\
\text { information }\end{array}$ & Survey & $\begin{array}{r}\text { Gross-quota } \\
\text { population }\end{array}$ & $\mathrm{BE}$ & $\begin{array}{l}\text { Respondents' interest in as well as } \\
\text { their FT concern and knowledge } \\
\text { about FT products exert a positive } \\
\text { effect on self-reported FT buying } \\
\text { behavior. Shopping inconvenience } \\
\text { does not have any effect on buying } \\
\text { behavior }\end{array}$ \\
\hline Goig (2007) & $\begin{array}{l}\text { Social psychology: } \\
\text { consumer attitudes as } \\
\text { global cognitive } \\
\text { orientation }\end{array}$ & $\begin{array}{l}\text { Survey and in-depth } \\
\text { interviews }\end{array}$ & $\begin{array}{l}\text { Simple random }+ \\
\text { convenience }\end{array}$ & ESP & $\begin{array}{l}\text { Respondents buying FT products } \\
\text { exhibit a higher level of global } \\
\text { cognitive orientation, yet trust in } \\
\text { international NGOs and social } \\
\text { responsibility moderate this effect }\end{array}$ \\
\hline $\begin{array}{l}\text { Grankvist et al. } \\
\text { (2007) }\end{array}$ & $\begin{array}{l}\text { Social psychology/ } \\
\text { marketing: product } \\
\text { information via labels, } \\
\text { consumer values }\end{array}$ & Lab experiment & Convenience & SWE & $\begin{array}{l}\text { Participants' liking of orange juice is } \\
\text { not affected by eco- or FT labels. } \\
\text { Participants showing high levels of } \\
\text { the value "warm relationships with } \\
\text { others" rated the taste of eco- and } \\
\text { FT labeled orange juice higher }\end{array}$ \\
\hline
\end{tabular}


Table 5 continued

\begin{tabular}{|c|c|c|c|c|c|}
\hline Study & Theoretical approach & Method & Sample & Country & Selected results \\
\hline $\begin{array}{l}\text { Shaw et al. } \\
\text { (2007) }\end{array}$ & $\begin{array}{l}\text { Social psychology: TPB } \\
\text { and purchasing } \\
\text { intentions }\end{array}$ & Survey & Purposive & UK & $\begin{array}{l}\text { Respondents' desire to avoid } \\
\text { sweatshop apparel and their } \\
\text { negative attitude towards such } \\
\text { clothing positively influence their } \\
\text { intention to avoid these kinds of } \\
\text { clothes }\end{array}$ \\
\hline $\begin{array}{r}\text { Nicholls and } \\
\text { Lee (2006) }\end{array}$ & $\begin{array}{l}\text { Social psychology: } \\
\text { TPB, consumer } \\
\text { socialization theory }\end{array}$ & $\begin{array}{l}\text { Focus group } \\
\text { discussions }\end{array}$ & Purposive & UK & $\begin{array}{l}\text { Discussants show knowledge about } \\
\text { and positive attitudes towards FT } \\
\text { products, yet due to missing brand } \\
\text { images of FT products, the children } \\
\text { surveyed are not inclined to buy } \\
\text { these }\end{array}$ \\
\hline $\begin{array}{l}\text { Ozcalgar- } \\
\text { Toulouse } \\
\text { et al. }(2006)\end{array}$ & $\begin{array}{l}\text { Social psychology: } \\
\text { modified TPB with } \\
\text { consumers' ethical } \\
\text { obligation and self- } \\
\text { identification }\end{array}$ & Survey & Convenience & $\mathrm{F}$ & $\begin{array}{l}\text { For respondents rarely buying FT } \\
\text { products, ethical obligation and } \\
\text { subj. norm positively affect buying } \\
\text { intention. For respondents often } \\
\text { buying FT products attitude, PBC, } \\
\text { and self-identity exert a positive } \\
\text { effect }\end{array}$ \\
\hline $\begin{array}{l}\text { Shaw et al. } \\
\text { (2006a) }\end{array}$ & $\begin{array}{l}\text { Sociology: consumption } \\
\text { as economic voting }\end{array}$ & In-depth interviews & Purposive & UK & $\begin{array}{l}\text { Interviewees frame their ethical } \\
\text { consumption behavior within } \\
\text { perceived collective consumer } \\
\text { behavior understood as voting in } \\
\text { the market sphere }\end{array}$ \\
\hline $\begin{array}{l}\text { Shaw et al. } \\
(2006 \mathrm{~b})\end{array}$ & $\begin{array}{l}\text { Social psychology: TPB } \\
\text { and consumers' } \\
\text { perceived behavioral } \\
\text { control }\end{array}$ & Survey & Purposive & UK & $\begin{array}{l}\text { Respondents' purchase decisions for } \\
\text { sweatshop-free clothes are } \\
\text { constrained by the difficulty finding } \\
\text { them, by the lack of information } \\
\text { about them, and the high price }\end{array}$ \\
\hline $\begin{array}{l}\text { Wright and } \\
\text { Heaton } \\
\text { (2006) }\end{array}$ & $\begin{array}{l}\text { Social psychology/ } \\
\text { marketing: } \\
\text { effectiveness of } \\
\text { communication, } \\
\text { information in FT }\end{array}$ & $\begin{array}{l}\text { Focus group } \\
\text { discussions }\end{array}$ & Convenience & UK & $\begin{array}{l}\text { Respondents' commitment to buy FT } \\
\text { products could be increased by } \\
\text { communicating the benefits of } \\
\text { these products and putting effort } \\
\text { into their branding }\end{array}$ \\
\hline $\begin{array}{r}\text { De Pelsmacker } \\
\text { et al. }(2005 \mathrm{~b})\end{array}$ & $\begin{array}{l}\text { Social psychology/ } \\
\text { marketing: product } \\
\text { information via labels } \\
\text { and attractiveness of } \\
\text { product features }\end{array}$ & Conjoint analysis & Convenience & $\mathrm{BE}$ & $\begin{array}{l}\text { Respondents exhibit highest purchase } \\
\text { intentions for coffee that they can } \\
\text { buy in supermarkets next to } \\
\text { conventional products and that is } \\
\text { labeled FT by the European Union }\end{array}$ \\
\hline $\begin{array}{l}\text { Littrell et al. } \\
\text { (2005) }\end{array}$ & $\begin{array}{l}\text { Social psychology/ } \\
\text { marketing: consumer } \\
\text { segments }\end{array}$ & Survey & Convenience & $\mathrm{USA}+\mathrm{CDN}$ & $\begin{array}{l}\text { Respondents differ in their attitudes } \\
\text { towards FT products according to } \\
\text { the generational cohort they belong } \\
\text { to }\end{array}$ \\
\hline $\begin{array}{l}\text { Shaw et al. } \\
(2005)\end{array}$ & $\begin{array}{l}\text { Social psychology: } \\
\text { consumer values } \\
\text { based on Schwartz's } \\
\text { value survey }\end{array}$ & $\begin{array}{l}\text { Focus group } \\
\text { discussions and in- } \\
\text { depth interviews }\end{array}$ & Purposive & UK & $\begin{array}{l}\text { Diverse set of values guide } \\
\text { respondents' decisions to buy FT } \\
\text { products: self-direction, } \\
\text { achievement, hedonism, security, } \\
\text { benevolence, and universalism }\end{array}$ \\
\hline $\begin{array}{l}\text { Carrigan et al. } \\
(2004)\end{array}$ & $\begin{array}{l}\text { Social psychology/ } \\
\text { marketing: consumer } \\
\text { segments }\end{array}$ & In-depth interviews & Purposive & UK & $\begin{array}{l}\text { Older respondents exhibit a sense of } \\
\text { moral responsibility, high level of } \\
\text { awareness, and a consciousness } \\
\text { about FT issues }\end{array}$ \\
\hline $\begin{array}{l}\text { Uusitalo and } \\
\text { Oksanen } \\
\text { (2004) }\end{array}$ & $\begin{array}{l}\text { Social psychology: } \\
\text { consumer attitudes } \\
\text { and perceived } \\
\text { behavioral control }\end{array}$ & Survey & Simple random & FIN & $\begin{array}{l}\text { Respondents believe that consumers' } \\
\text { ability to promote ethical trade is } \\
\text { poor. Purchase decisions are } \\
\text { constrained by lack of information } \\
\text { about FT products and ethical } \\
\text { product alternatives as well as retail } \\
\text { outlets and higher prices }\end{array}$ \\
\hline
\end{tabular}


Table 5 continued

\begin{tabular}{|c|c|c|c|c|c|}
\hline Study & Theoretical approach & Method & Sample & Country & Selected results \\
\hline $\begin{array}{l}\text { Tanner and } \\
\text { Kast } \\
(2003)\end{array}$ & $\begin{array}{l}\text { Social psychology: } \\
\text { consumer attitudes } \\
\text { and perceived } \\
\text { behavioral control }\end{array}$ & Survey & Simple random & $\mathrm{CH}$ & $\begin{array}{l}\text { Respondents' positive attitudes } \\
\text { towards environmental protection, } \\
\text { FT, and local products support } \\
\text { purchases of organically grown } \\
\text { food. Price does not constrain } \\
\text { respondents' purchasing decisions }\end{array}$ \\
\hline $\begin{array}{l}\text { Shaw and } \\
\text { Newholm } \\
(2002)\end{array}$ & $\begin{array}{l}\text { Sociology: consumer } \\
\text { identity as voluntary } \\
\text { simplicity }\end{array}$ & $\begin{array}{l}\text { Focus group } \\
\text { discussions and in- } \\
\text { depth interviews }\end{array}$ & Purposive & UK & $\begin{array}{l}\text { Interviewees regard FT consumption } \\
\text { as a means to maintain consumption } \\
\text { levels but modify their consumption } \\
\text { behavior and present the morality of } \\
\text { their life-style }\end{array}$ \\
\hline $\begin{array}{l}\text { Shaw et al. } \\
(2000)\end{array}$ & $\begin{array}{l}\text { Social psychology: } \\
\text { modified TPB with } \\
\text { consumers' ethical } \\
\text { obligation and self- } \\
\text { identity }\end{array}$ & Survey & Purposive & UK & $\begin{array}{l}\text { Concepts of ethical obligation and } \\
\text { self-identity independently influence } \\
\text { respondents' behavioral intention to } \\
\text { buy FT products. Influence of } \\
\text { subjective norm decreases when } \\
\text { PBC is added }\end{array}$ \\
\hline $\begin{array}{l}\text { Kim et al. } \\
\text { (1999) }\end{array}$ & $\begin{array}{l}\text { Social psychology: } \\
\text { consumer attitudes }\end{array}$ & Survey & Convenience & USA & $\begin{array}{l}\text { Respondents' purchasing intentions } \\
\text { for FT apparel are positively } \\
\text { influenced by their socially } \\
\text { responsible attitudes }\end{array}$ \\
\hline $\begin{array}{l}\text { Shaw and } \\
\text { Clarke } \\
(1999)\end{array}$ & $\begin{array}{l}\text { Social psychology: ТPB } \\
\text { and consumer belief } \\
\text { formation }\end{array}$ & $\begin{array}{l}\text { Focus group } \\
\text { discussions }\end{array}$ & Purposive & UK & $\begin{array}{l}\text { Respondents' beliefs, which are } \\
\text { assumed to influence respondents' } \\
\text { attitudes, are formed by various } \\
\text { normative and broader } \\
\text { environmental factors such as family } \\
\text { and friends, ethical organizations or } \\
\text { religion }\end{array}$ \\
\hline
\end{tabular}

Notes: Publications are ordered chronologically by year (with the latest publication at the beginning) and within each year alphabetically by first author

AUS Australia, BE Belgium, CDN Canada, $C H$ Switzerland, $D$ Germany, ESP Spain, $F$ France, FIN Finland, $H K$ Hong Kong, $I T$ Italy, $N L$ Netherlands, ROK South Korea, SWE Sweden, UK United Kingdom, USA United States of America, FT Fair Trade, $P B C$ perceived behavioral control, $T P B$ theory of planned behavior, SVT Schwartz's value theory

\section{References}

\section{* = Article included in the review}

*Adams, M., \& Raisborough, J. (2010). Making a difference: Ethical consumption and the every day. The British Journal of Sociology, 61, 256-274.

Ajzen, I. (1991). The theory of planned behavior. Organizational Behavior and Human Decision Processes, 50, 179-211.

Andreoni, J. (1990). Impure altruism and donations to public goods: A theory of warm-glow giving. The Economic Journal, 100, 464-477.

Armitage, C. J., \& Conner, M. (2001). Efficacy of the theory of planned behaviour: A meta-analytic review. British Journal of Social Psychology, 40, 471-499.

*Arnot, C., Boxall, P. C., \& Cash, S. B. (2006). Do ethical consumers care about price? A revealed preference analysis of Fair Trade coffee purchases. Canadian Journal of Agricultural Economics, 54, 555-565.

*Auger, P., Burke, P., Devinney, T. M., \& Louviere, J. J. (2003). What will consumers pay for social product features? Journal of Business Ethics, 42, 281-304.
Auger, P., \& Devinney, T. M. (2007). Do what consumers say matter? The misalignment of preferences with unconstrained ethical intentions. Journal of Business Ethics, 76, 361-383.

Auger, P., Devinney, T. M., \& Louviere, J. J. (2007). Using bestworst scaling methodology to investigate consumer ethical beliefs across countries. Journal of Business Ethics, 70, 299-326.

Barnett, C., Cloke, P., Clarke, N., \& Malpass, A. (2005). Consuming ethics: Articulating the subjects and spaces of ethical consumption. Antipode, 37, 23-45.

*Basu, A. K., \& Hicks, R. L. (2008). Label performance and the willingness to pay for Fair Trade coffee: A cross-national perspective. International Journal of Consumer Studies, 32, $470-478$.

Bateman, I. J., et al. (2002). Economic valuation with stated preference techniques. A manual. Cheltenham: Edward Elgar.

Bauman, Z. (1988). Freedom. Milton Keynes: Open University Press.

Becchetti, L., \& Rosati, F. C., (2007). Global social preferences and the demand for socially responsible products: Empirical evidence from a pilot study on Fair Trade consumers. The World Economy 807-836.

Belk, R. W., Devinney, T., \& Eckhardt, G. (2005). Consumer ethics across cultures. Consumption, Markets and Culture, 8, 275-289. 
*Cailleba, P., \& Casteran, H. (2010). Do ethical values work? A quantitative study on the impact of fair trade coffee on consumer behavior. Journal of Business Ethics, 97, 613-624.

Callero, P. L. (2003). The sociology of the self. Annual Review of Sociology, 29, 115-133.

*Carlsson, F., García, J. H., \& Löfgren, Â. (2010). Conformity and the demand for environmental goods. Environmental Resource Economics, 47, 407-421.

*Carrigan, M., Szmigin, I., \& Wright, J. (2004). Shopping for a better world? An interpretive study of the potential for ethical consumption within the older market. Journal of Consumer Marketing, 21, 401-417.

Carrington, M. J., Neville, B. A., \& Whitwell, G. J. (2010). Why ethical consumers don't walk their talk: Towards a framework for understanding the gap between the ethical purchase intentions and actual buying behaviour of ethically minded consumers. Journal of Business Ethics, 97, 139-158.

Carson, R. (2000). Contingent valuation: A user's guide. Environmental Science and Technology, 34, 1413-1418.

Carson, R., \& Hanemann, W. M. (2005). Contingent valuation. In K.-G. Mäler \& J. R. Vincent (Eds.), Handbook of environmental economics. Valuing environmental changes (Vol. 2, pp. 821-936). Amsterdam: Elsevier.

Cerulo, K. A. (1997). Identity construction: New issues, new directions. Annual Review of Sociology, 23, 385-409.

*Chatzidakis, A., Hibbert, S., \& Smith, A. P. (2007). Why people don't take their concerns about fair trade to the supermarket: The role of neutralisation. Journal of Business Ethics, 74, 89-100.

Connolly, J., \& Shaw, D. (2006). Identifying fair trade in consumption choice. Journal of Strategic Marketing, 14, 353-368.

*Cranfield, J., Henson, S., Northey, J., \& Masakure, O. (2010). An assessment of consumer preference for Fair Trade coffee in Toronto and Vancouver. Agribusiness, 26, 307-325.

*d'Astous, A., \& Mathieu, S. (2008). Inciting consumers to buy fairly-traded products: A field experiment. Journal of Consumer Marketing, 25, 149-157.

*de Ferran, F., \& Grunert, K. G. (2007). French fair trade coffee buyers' purchasing motives: An exploratory study using meansend chains analysis. Food Quality and Preference, 18, 218-229.

*De Pelsmacker, P., Driesen, L., \& Rayp, G. (2005a). Do consumers care about ethics? Willingness to pay for fair-trade coffee. Journal of Consumer Affairs, 39, 363-385.

*De Pelsmacker, P., \& Janssens, W. (2007). A model for fair trade buying behaviour: The role of perceived quantity and quality of information and of product-specific attitudes. Journal of Business Ethics, 75, 361-380.

*De Pelsmacker, P., Janssens, W., Streckx, E., \& Mielants, C. (2005b). Consumer preferences for the marketing of ethically labelled coffee. International Marketing Review, 22, 512-530.

Deutsch, M. (1975). Equity, equality, and need: What determines which value will be used on the basis of distributive justice? Journal of Social Issues, 31, 137-149.

Dickinson, R. A., \& Carsky, L. (2005). The consumer as economic voter. In R. Harrison, T. Newholm, \& D. Shaw (Eds.), The ethical consumer (pp. 25-36). London: Sage.

*Dickson, M. A. (2001). The utillity of no sweat labels for apparel consumers: Profiling label users and predicting their purchases. The Journal of Consumer Affairs, 35, 96-119.

*Didier, T., \& Lucie, S. (2008). Measuring consumer's willingness to pay for organic and Fair Trade products. International Journal of Consumer Studies, 32, 479-490.

*Doran, C. J. (2009). The role of personal values in Fair Trade consumption. Journal of Business Ethics, 84, 549-563.

*Doran, C. J. (2010). Fair Trade consumption: In support of the outgroup. Journal of Business Ethics, 95, 527-541.
*Doran, C. J., \& Natale, S. M. (2011). $\varepsilon \mu \pi \dot{\alpha} \theta \varepsilon l \alpha$ (Empatheia) and Caritas: The role of religion in Fair Trade consumption. Journal of Business Ethics, 98, 1-15.

Ford, R. C., \& Richardson, W. D. (1994). Ethical decision making: A review of the empirical literature. Journal of Business Ethics, 13, 205-221.

Friedman, M. (1996). A positive approach to organized consumer action: The "Buycott" as an alternative to the Boycott. Journal of Consumer Policy, 19, 439-451.

Gabriel, Y., \& Lang, T. (2006). The unmanageable consumer. Sage: London.

*Galarraga, I., \& Markandya, A. (2004). Economic techniques to estimate the demand for sustainable products: A case study for Fair Trade and organic coffee in the United Kingdom. Economia Agraria y Recursos Naturales, 4, 109-134.

Giddens, A. (1991). Modernity and self-identity. Standford: Standford University Press.

*Goig, R. L. (2007). Fair trade and global cognitive orientation: A focus on Spanish fair trade consumers. International Journal of Consumer Studies, 31, 468-477.

*Grankvist, G., Lekedal, H., \& Marmendal, M. (2007). Values and eco- and fair-trade labelled products. British Food Journal, 109, $169-181$.

Green, C., \& Tunstall, S. (1999). A psychological perspective. In I. J. Bateman \& K. G. Willis (Eds.), Valuing environmental preferences. Theory and practice of the contingent valuation method in the US, EU, and developing countries (pp. 207-257). Oxford: Oxford University Press.

Gutman, J. (1982). A means-end chain model based on consumer categorization processes. Journal of Marketing, 46, 60-72.

*Halepete, J., Littrell, M., \& Park, J. (2009). Personalization of Fair Trade apparel. Consumer attitudes and intentions. Clothing \& Textiles Research Journal, 27, 143-160.

Hanley, N., Wright, R. E., \& Adamowicz, V. (1998). Using choice experiments to value the environment. Environmental \& Resource Economics, 11, 413-428.

Harrison, G. W., \& List, J. A. (2004). Field experiments. Journal of Economic Literature, 42, 1009-1055.

*Hertel, S., Scruggs, L., \& Heidkamp, C. P. (2009). Human rights and public opinion: From attitudes to action. Political Science Quarterly, 143, 443-459.

Howard, P. H., \& Allen, P. (2008). Consumer willingness to pay for domestic 'fair trade': Evidence from the United States. Renewable Agriculture and Food Systems, 23, 242-253.

*Howard, P. H., \& Allen, P. (2010). Beyond Organic and Fair Trade? An analysis of ecolabel preferences in the United States. Rural Sociology, 75, 244-269.

*Hustvedt, G., \& Bernard, J. C. (2010). Effects of social responsibility labelling and brand on willingness to pay for apparel. International Journal of Consumer Studies, 34, 619-626.

Kahneman, D., Ritov, I., \& Schkade, D. (1999). Economic preferences or attitude expressions? An analysis of dollar responses to public issues. Journal of Risk and Uncertainty, 19, 203-235.

*Kim, S., Littrell, M. A., \& Paff Ogle, J. L. (1999). The relative importance of social responsibility as a predictor of purchase intentions for clothing. Journal of Fashion Marketing and Management, 3, 207-218.

*Kim, G.-S., Lee, G. Y., \& Park, K. (2010). A cross-national investigation on how ethical consumers build loyalty toward Fair Trade brands. Journal of Business Ethics, 96, 589-611.

Krier, J.-M. (2008). Fair Trade 2007: New facts and figures from an ongoing success story. Culemborg: DAWS.

Lancaster, K. J. (1966). A new approach to consumer theory. The Journal of Political Economy, 74, 132-157.

Lawson, R. (2010). Consumer behaviour. In M. Baker \& M. Saren (Eds.), Marketing theory a student text (pp. 263-280). Los Angeles: Sage. 
Levitt, S. D., \& List, J. A. (2007). What do laboratory experiments measuring social preferences reveal about the real world? Journal of Economic Perspectives, 21, 153-174.

List, J. A. (2003). Using random nth price auctions to value nonmarket goods and services. Journal of Regulatory Economics, 23, 193-205.

*Littrell, M. A., Yoon, J. M., \& Halepete, J. (2005). Generation X, baby boomers, and swing: Marketing fair trade apparel. Journal of Fashion Marketing and Management, 9, 407-419.

*Loureiro, M. L., \& Lotade, J. (2005). Do fair trade and eco-labels in coffee wake up the consumer conscience? Ecological Economics, 53, 129-138.

Louviere, J. J., Hensher, D. A., \& Swait, J. D. (2000). Stated choice methods. Analysis and Application. Cambridge: Cambridge University Press.

McFadden, D. (1974). Conditional logit analysis of qualitative choice behavior. In P. Zarembka (Ed.), Frontiers in econometrics (pp. 105-142). New York: Academic Press.

Miller, D. (1992). Distributive justice: What the people think? Ethics, 102, 555-593

Newholm, T., \& Shaw, D. (2007). Studying the ethical consumer: A review of research. Journal of Consumer Behavior, 6, 253-270.

*Nicholls, A., \& Lee, N. (2006). Purchase decision-making in fair trade and the ethical purchase 'gap': Is there a fair trade twix? Journal of Strategic Marketing, 14, 369-386.

*Nijssen, E. J., \& Douglas, S. P. (2008). Consumer world-mindedness, social-mindedness, and store image. Journal of International Marketing, 16, 84-107.

O'Fallon, M. J., \& Butterfield, K. D. (2005). A review of the empirical ethical decision-making literature: 1996-2003. Journal of Business Ethics, 59, 375-413.

Opp, K.-D. (1999). Contending conceptions of the theory of rational action. Journal of Theoretical Politics, 11, 171-202.

*Ozcaglar-Toulouse, N., Shiu, E., \& Shaw, D. (2006). In search of fair trade: Ethical consumer decision making in France. International Journal of Consumer Studies, 30, 502-514.

Palmquist, R. B. (1991). Hedonic methods. In J. B. Barden \& C. D. Kolstad (Eds.), Measuring the demand for environmental quality (pp. 77-120). North Holland: Elsevier.

*Poelman, A., Mojet, J., Lyon, D., \& Sefa-Dedeh, S. (2008). The influence of information about organic production and fair trade on preferences for and perception of pineapple. Food Quality and Preference, 19, 114-121.

Portes, A. (1998). Social capital. Its origins and applications in modern sociology. Annual Review of Sociology, 24, 1-24.

*Prasad, M., Kimeldorf, H., Meyer, R., \& Robinson, I. (2004). Consumers of the World Unite: A market-based response to sweatshops. Labor Studies Journal, 29, 57-80.

Putnam, R. (1993). Making democracy work: Civic traditions in modern Italy. Princeton: Princeton University Press.

Reiley, D. H., \& List, J. A. (2008). Field experiments in economics. In S. N. Durlauf \& L. E. Blume (Eds.), The New Palgrave dictionary of economics. New York: Palgrave.

*Rode, J., Hogarth, R. M., \& Le Menestrel, M. (2008). Ethical differentiation and market behavior: An experimental approach. Journal of Economic Behavior \& Organization, 66, 265-280.

*Rousu, M. C., \& Corrigan, J. R. (2008). Estimating the welfare loss to consumers when food labels do not adequately inform: An application to fair trade certification. Journal of Agricultural \& Food Industrial Organization 6(1), article 3.

Schwartz, S. H. (1977). Normative influences on Altruism. Advances in Experimental Social Psychology, 10, 221-279.

Schwartz, S. H. (1994). Are there universal aspects in the structure and contents of human values. Journal of Social Issues, 50, $19-45$.
Schwartz, S. H., \& Bilsky, W. (1990). Toward a theory of the universal content and structure of values: Extentions and crosscultural replications. Journal of Personality and Social Psychology, 58, 878-891.

*Shaw, D., \& Clarke, I. (1999). Belief formation in ethical consumer groups: An exploratory study. Marketing Intelligence \& Planning, 17, 109-119.

*Shaw, D., \& Newholm, T. (2002). Voluntary simplicity and the ethics of consumption. Psychology \& Marketing, 19, 167-185.

*Shaw, D., Grehan, E., Shiu, E., Hassan, L., \& Thomson, J. (2005). An exploration of values in ethical consumer decision making. Journal of Consumer Behaviour, 4, 185-200.

*Shaw, D., Newholm, T., \& Dickinson, R. (2006a). Consumption as voting: An exploration of consumer empowerment. European Journal of Marketing, 40, 1049-1067.

*Shaw, D., Hogg, G., Wilson, E., Shiu, E., \& Hassan, L. (2006b). Fashion victim: The impact of Fair Trade concerns on clothing choice. Journal of Strategic Marketing, 14, 427-440.

*Shaw, D., Shiu, E., \& Clarke, I. (2000). The contribution of ethical obligation and self-identity to the theory of planned behaviour: An exploration of ethical consumers. Journal of Marketing Management, 16, 879-894.

*Shaw, D., Shiu, E., Hassan, L., Bekin, C., \& Hogg, G. (2007) Intending to be ethical: An examination of consumer choice in sweatshop avoidance. Advances in Consumer Research, 34, 31-38.

Soron, D. (2010). Sustainability, self-identity and the sociology of consumption. Sustainable Development, 18, 172-181.

Sugden, R. (1999). Alternatives to the neo-classical theory of choice. In I. J. Bateman \& K. G. Willis (Eds.), Valuing environmental preferences theory and practice of the contingent valuation method in the US, EU, and developing countries (pp. 152-180). Oxford: Oxford University Press.

Tajfel, H., \& Turner, J. (1986). The social identity theory of intergroup behavior. In S. Worchel \& W. G. Austin (Eds.), Psychology of intergroup relations (pp. 7-24). Chicago: Nelson-Hall.

Tallontire, A., Rentsendorj, E. \& Blowfield, M., 2001. Ethical consumers and ethical trade: A review of current literature. Series 12. Chatham: Natural Resource Institute Policy.

*Tanner, C., \& Kast, S. W. (2003). Promotine sustainable consumption: Determinants of green purchases by Swiss consumers. Psychology \& Marketing, 20, 883-902.

*Trudel, R., \& Cotte, J. (2009). Does it pay to be good? MIT Sloane Management Review, 50, 61-68.

*Uusitalo, O., \& Oksanen, R. (2004). Ethical consumerism: A view from Finland. International Journal of Consumer Studies, 28, 214-221.

*Varul, M. Z. (2009). Ethical selving in cultural contexts: Fairtrade consumption as an everyday ethical practice in the UK and Germany. International Journal of Consumer Studies, 33, 183-189.

*Varul, M. Z. (2010). Ethical consumption: The case of Fair Trade. Kölner Zeitschrift für Soziologie und Sozialpsychologie, Sonderheft, 49, 366-385.

*Wright, L. T., \& Heaton, S. (2006). Fair Trade marketing: An exploration through qualitative research. Journal of Strategic Marketing, 14, 411-426.

Zander, K., \& Hamm, U. (2010). Consumer preferences for additional ethical attributes of organic food. Food Quality and Preference, 21, 495-503.

Zukin, S., \& Maguire, J. S. (2004). Consumers and consumption. Annual Review of Sociology, 30, 173-197. 